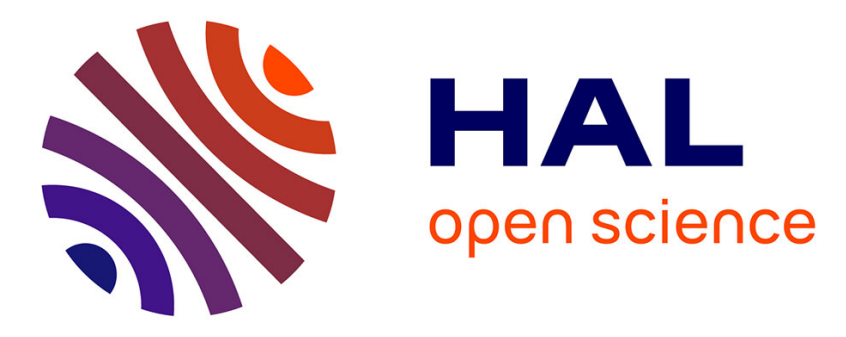

\title{
New erythritol derivatives from the fertile form of Roccella montagnei
}

Thuc Huy Duong, Bui Linh Chi Huynh, Warinthorn Chavasiri, Marylene

Chollet-Krugler, van Kieu Nguyen, Thi Hoai Thu Nguyen, Poul Erik Hansen, Pierre Le Pogam, Holger Thüs, Joël Boustie, et al.

\section{To cite this version:}

Thuc Huy Duong, Bui Linh Chi Huynh, Warinthorn Chavasiri, Marylene Chollet-Krugler, van Kieu Nguyen, et al.. New erythritol derivatives from the fertile form of Roccella montagnei. Phytochemistry, 2017, 137, pp.156-164. 10.1016/j.phytochem.2017.02.012 . hal-01501264

\section{HAL Id: hal-01501264 https://hal-univ-rennes1.archives-ouvertes.fr/hal-01501264}

Submitted on 23 Oct 2017

HAL is a multi-disciplinary open access archive for the deposit and dissemination of scientific research documents, whether they are published or not. The documents may come from teaching and research institutions in France or abroad, or from public or private research centers.
L'archive ouverte pluridisciplinaire HAL, est destinée au dépôt et à la diffusion de documents scientifiques de niveau recherche, publiés ou non, émanant des établissements d'enseignement et de recherche français ou étrangers, des laboratoires publics ou privés. 


\section{New erythritol derivatives from the fertile form of Roccella montagnei}

Thuc Huy Duong, ${ }^{a}$ Bui Linh Chi Huynh, ${ }^{b}$ Warinthorn Chavasiri, ${ }^{c}$ Marylene Chollet-Krugler, ${ }^{\text {d }}$ Van Kieu Nguyen, ${ }^{\mathrm{c}}$ Thi Hoai Thu Nguyen, ${ }^{\mathrm{e}}$ Poul Erik Hansen, ${ }^{\mathrm{f}}$ Pierre Le Pogam, ${ }^{\mathrm{d}, \mathrm{g}}$ Holger Thüs, ${ }^{\mathrm{h}}$ Joël Boustie, ${ }^{\mathrm{d}^{*}}$ and Kim Phi Phung Nguyen ${ }^{b^{*}}$

a Department of Chemistry, Ho Chi Minh City University of Pedagogy, 280 An Duong Vuong Street, District 5, Ho Chi Minh City 748342, Vietnam,

${ }^{b}$ Department of Organic Chemistry, University of Science, National University - Ho Chi Minh City, 227 Nguyen Van Cu Str., Dist. 5, Ho Chi Minh City 748355, Vietnam,

${ }^{c}$ Natural Products Research Unit, Department of Chemistry, Faculty of Science, Chulalongkorn University, Phayathai Rd., Patumwan, Bangkok 10330, Thailand,

${ }^{d}$ Institute of Chemistry of Rennes, ISCR, UMR CNRS 6226, University of Rennes 1, 2 Av. du Pr. Léon Bernard, Rennes Cedex 35043, France,

${ }^{e}$ Department of Basic Science, Ho Chi Minh City University of Medicine and Pharmacy, 217 Hong Bang Street, Dist. 5, Ho Chi Minh City 749051, Vietnam,

${ }^{f}$ Department of Science, Systems, and Models, Roskilde University, 260 Postboks, Roskilde 4000, Denmark,

${ }^{g}$ Institute of Electronics and Telecommunications of Rennes (IETR), UMR CNRS 6164, University of Rennes 1, 263 Av. du Général Leclerc, Rennes Cedex 35042 Rennes, France

${ }^{h}$ Life Science Department, The Natural History Museum, Cromwell Road, SW7 5BD London, England.

* These two authors contributed equally to this work.

Kim Phi Phung Nguyen

Tel.: +84.801226966 660

E-mail address: kimphiphung@yahoo.fr

Joël Boustie

Tel.: +33632826939

E-mail address: joel.boustie@univ-rennes1.fr 


\begin{abstract}
Chemical investigation of the methanol extract of the fertile form of Roccella montagnei collected in Vietnam afforded twelve secondary metabolites, including five new montagnetol derivatives, orsellinylmontagnetols A-D (1-4) and a furanyl derivative (5) together with seven known compounds. Their chemical structures were elucidated by analysis of 1D and 2D NMR and high resolution mass spectroscopic data. The relative stereochemistry of two chiral centers (C-2 and C-3) of 1-2 was elucidated by comparison of their coupling constants and the specific rotation with those reported in the literature while the absolute stereochemistry was determined by the application of a modified Mosher method for the hydroxy group at C-3 in $\mathbf{1}$ and 2. The absolute configuration $(2 R, 3 S)$ of the butanetetraol moiety of these compounds is in accordance with that of erythrin, a recognized chemotaxonomic marker of the genus Roccella. Compounds 1, 3, 5, 6, and 8 were evaluated for their cytotoxic activities against four cancer cell lines. Only compound $\mathbf{1}$ exerted a moderate activity against MCF-7 cell line with an $\mathrm{IC}_{50}$ value of $68.39 \pm 3.46 \mu \mathrm{M}$.
\end{abstract}

Key words: lichen, Roccella montagnei (fertile form), montagnetol, montagnetol derivatives, stereochemistry, cytotoxicity 


\section{Introduction}

Lichens are symbiotic systems consisting of a mycobiont (the dominating fungal partner), one or more photobionts (algal partner) and a complex microbial consortium comprising a wide array of heterotrophic bacteria and fungi (Grube and Berg, 2009; Spribille et al., 2016) with more than 1,000 specialized metabolites described so far from lichen sources. The majority of secondary metabolites are produced by the fungal partner (Nash, 2008), and display specific chemical skeletons (StockerWörgotter, 2008; Elix, 2014). In a given species, quantities and in some cases the nature of these extrolites can be modified according to ecological and physiological conditions (Bialonska and Dayan, 2005; Stocker-Wörgötter, 2008). Nowadays, innovative analytical techniques help pinpointing new metabolites and streamlining their isolation with high probability to obtain bioactive compounds (Boustie and Grube, 2005).

Lichens from coastal habitats in Vietnam have seldom been studied chemically. In the course of our systematic research on lichen substances from the Vietnamese biota, we have examined the fertile form of the lichen Roccella montagnei (syn. R. bellangeriana), which occurs in the southern part of Vietnam and that has not yet been studied with chemical and biological methods apart from scarce data obtained by thin layer chromatography (Aptroot and Schumm, 2011).

Phytochemical studies on lichens Roccella spp. have been conducted over more than one hundred years (Hesse, 1906) showing that these lichens produce a diverse range of metabolites such as meso-erythritol (Huneck and Follmann, 1967), dibenzofurans (Culberson, 1969; Huneck et al., 1991; 1993; 1996; 2001), chromones (Aberhart and Overton, 1969; Huneck et al., 1972; 1992), Ncontaining compounds (Bohman-Lindgren et Ragnarsson, 1972; Ramakrishnan and Subramanian, 1964), carbohydrates (Carbonero et al., 2005), terpenoids (Murty and Subramanian, 1958; 1959). Among them, erythrin and lecanoric acid were found in most Roccella species (Tehler et al., 2010) with the former being reported as a principal secondary product reaching up to $7.3 \%$ in $R$. montagnei (Feige et al., 1986; Huneck and Follmann, 1967; Thadhani et al., 2010; Parrot et al., 2015). The genus Roccella has been recently revised, describing 24 main species which are restricted to coastal habitats (Tehler et al., 2010).

We herein report on the isolation and structure elucidation of five new compounds, using the Mosher's method to assess their stereochemistry. The cytotoxic activities at the concentration of $100 \mu \mathrm{g} / \mathrm{mL}$ against liver hepatocellular carcinoma (HepG2), human lung cancer (NCI-H460), cervical cancer (Hela) and human breast cancer (MCF-7) cell lines were evaluated for five compounds $\mathbf{1}, \mathbf{3}, \mathbf{5}, \mathbf{6}$, and $\mathbf{8}$.

\section{Results and discussion}


The fertile form of Roccella montagnei thalli were collected on tree barks in Tuy Phong district, Binh Thuan province, Vietnam. A detailed chromatographic fractionation of its methanol extract led to the isolation of five new compounds (1-5) alongside seven metabolites (6-12) already described (Fig. 1).<smiles>[R]C[C@@H]([R20])[C@@H]([R20])[C@H](C)OC(=O)c1c(C)cc(O)cc1O</smiles>

$\begin{array}{llll}\mathbf{1} & \mathrm{R}^{1}=\mathrm{H} & \mathrm{R}^{2}=\mathrm{H} & \mathrm{R}^{3}=\mathrm{X} \\ \mathbf{1 S} & \mathrm{R}^{1}=(S) \text {-MTPA } & \mathrm{R}^{2}=\mathrm{H} & \mathrm{R}^{3}=\mathrm{X} \\ \mathbf{1} \boldsymbol{R} & \mathrm{R}^{1}=(R) \text {-MTPA } & \mathrm{R}^{2}=\mathrm{H} & \mathrm{R}^{3}=\mathrm{X} \\ \mathbf{2} & \mathrm{R}^{1}=\mathrm{H} & \mathrm{R}^{2}=\mathrm{X} & \mathrm{R}^{3}=\mathrm{H} \\ \mathbf{2 S} & \mathrm{R}^{1}=(S) \text { MTPA } & \mathrm{R}^{2}=\mathrm{X} & \mathrm{R}^{3}=\mathrm{H} \\ \mathbf{2} \boldsymbol{R} & \mathrm{R}^{1}=(R) \text {-MTPA } & \mathrm{R}^{2}=\mathrm{X} & \mathrm{R}^{3}=\mathrm{H} \\ \mathbf{3} & \mathrm{R}^{1}=\mathrm{X} & \mathrm{R}^{2}=\mathrm{H} & \mathrm{R}^{3}=\mathrm{H} \\ \mathbf{4} & \mathrm{R}^{1}=\mathrm{X} & \mathrm{R}^{2}=\mathrm{H} & \mathrm{R}^{3}=\mathrm{X} \\ \mathbf{6} & \mathrm{R}^{1}=\mathrm{H} & \mathrm{R}^{2}=\mathrm{H} & \mathrm{R}^{3}=\mathrm{H}\end{array}$<smiles>Cc1cc(O)cc(O)c1C(=O)OC1COCC1O</smiles>

5

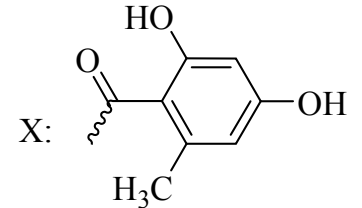

$\mathrm{R}^{3}=\mathrm{X}$$$
\mathrm{R}^{3}=\mathrm{X}
$$

$\mathrm{R}^{3}=\mathrm{H}$

$\mathrm{R}^{3}=\mathrm{H}$

$\mathrm{R}^{3}=\mathrm{H}$

$\mathrm{R}^{3}=\mathrm{H}$

$\mathrm{R}^{3}=\mathrm{H}$<smiles>CC(=O)OC[C@@H](O)[C@H](O)CO</smiles><smiles>[R]c1c(C)cc(OC(=O)c2c(C)cc(O)cc2O)cc1O</smiles><smiles>O=CCC(=O)OC[C@@H](O)[C@@H](O)CO</smiles>

$9 \mathrm{R}=\mathrm{COOH}$

$10 \mathrm{R}=\mathrm{H}$<smiles>[R]c1c(C)cc(O)cc1O</smiles>

$11 \mathrm{R}=\mathrm{COOH}$

Fig. 1. Chemical structures of 1-12

D-(+)-Montagnetol (6), D-(+)-erythrin (8) and lecanoric acid (9) are the main markers of $R$. montagnei (Huneck and Folhman, 1967; Basset et al., 2010; Thadhani et al., 2010) and were isolated as major compounds of this lichen. Besides orsellinic acid (11) and methyl orsellinate (12) (Lopes et al., 2008) which correspond to monoaromatic moieties found in many lichens, five new montagnetol derivatives (1-5) were isolated from $R$. montagnei. The relative stereochemistry of the two chiral centers, C-2 and C-3 of orsellinylmontagnetols A-D was elucidated by comparison of their coupling constants and their specific rotation with those reported in the literature (Basset et al., 2010; Hawkes and Lewis, 1984) while the absolute stereochemistry was determined by the application of a modified Mosher method (Hoye et al., 2007) for a hydroxy group at C-3 in 1 and 2. Among the new isolated products, the structure of 5, a ring-closure derivative of $\mathbf{6}$, reveals an unusual structural feature. 


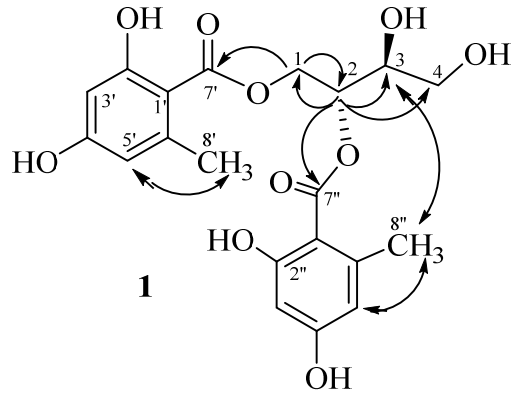

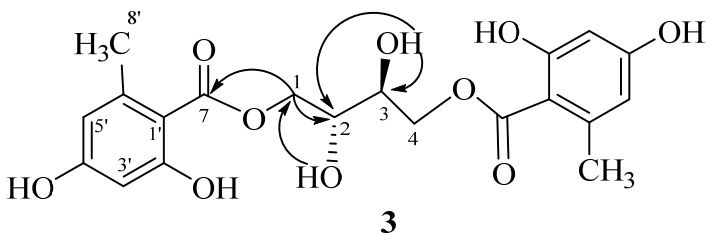

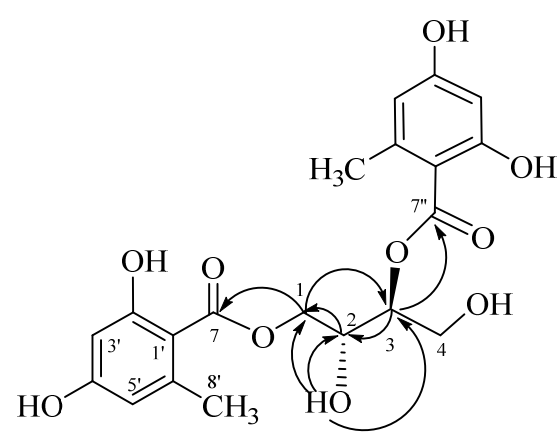

2

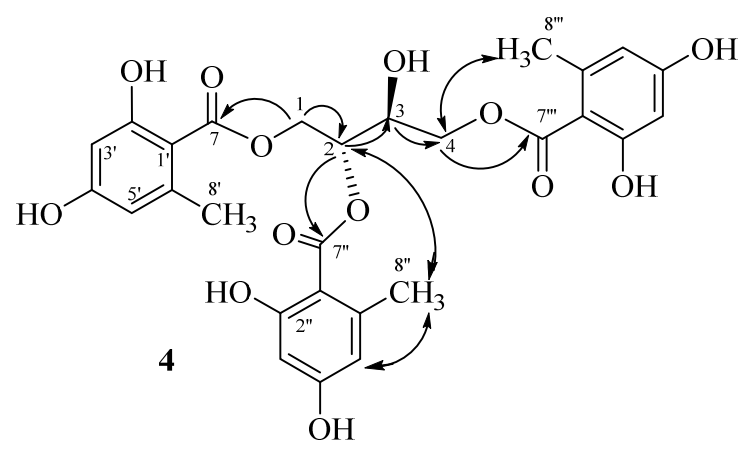

Fig. 2. Key HMBC and NOESY correlations of compounds 1-4

$$
1 S \quad \Delta \delta_{4 \mathrm{a}, 4 \mathrm{~b}}=0.200 \mathrm{ppm}
$$
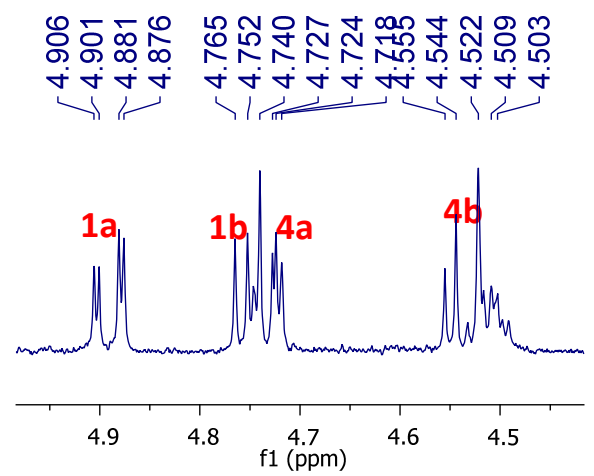

$1 R \quad \Delta \delta_{4 \mathrm{a}, 4 \mathrm{~b}}=\mathbf{0 . 0 7 0} \mathrm{ppm}$

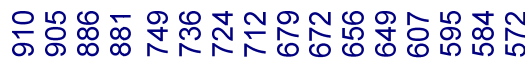

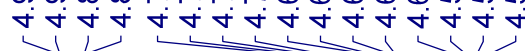

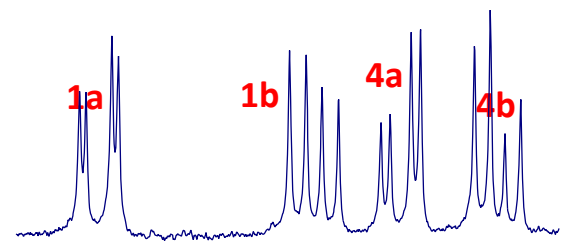

$\begin{array}{llllllllll}4.95 & 4.90 & 4.85 & 4.80 & 4.75 & 4.70 & 4.65 & 4.60 & 4.55\end{array}$
$2 S \Delta \delta_{4 \mathrm{a}, 4 \mathrm{~b}}=0.060 \mathrm{ppm}$

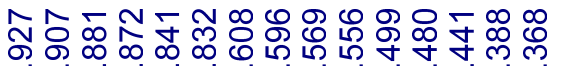
ن்

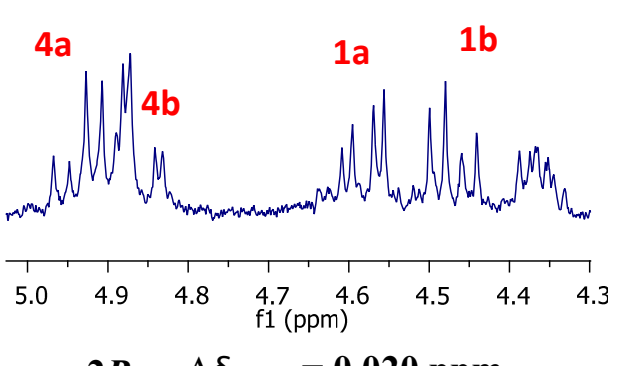

$2 R \quad \Delta \delta_{4 \mathrm{a}, 4 \mathrm{~b}}=0.020 \mathrm{ppm}$
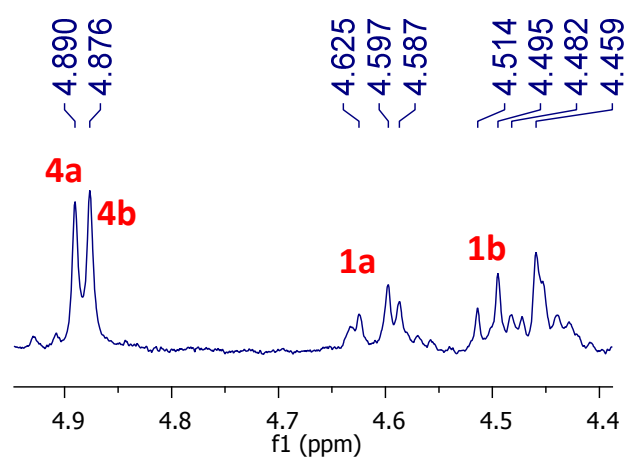

Fig. 3. Proton signal patterns of $\mathrm{H}_{2}-4$ of $(S)$ - and (R)-MTPA esters of $\mathbf{1}$ (1S and $\mathbf{1} \boldsymbol{R}$, respectively) (left) and 2 ( $2 S$ and $2 R$, respectively) (right) 
Compound 1 was isolated as an optically active white amorphous powder and the molecular formula was established to be $\mathrm{C}_{20} \mathrm{H}_{22} \mathrm{O}_{10}$ based on the negative-ion mode HRESIMS data $(\mathrm{m} / z$ $421.1128[\mathrm{M}-\mathrm{H}]^{-}$, calcd for $\left.\mathrm{C}_{20} \mathrm{H}_{22} \mathrm{O}_{10}-\mathrm{H}, 421.1140\right)$. The ${ }^{1} \mathrm{H}$ NMR spectrum, in accordance with ${ }^{13} \mathrm{C}$ and HSQC spectra (Table 1), revealed two aromatic methyls ( $\delta_{\mathrm{H}} 2.50$ and $2.41, \delta_{\mathrm{C}} 24.4$ and $24.5)$, two pairs of meta-coupled methines $\left(\delta_{\mathrm{H}} 6.21,6.23\right.$, each $d, 2.0 \mathrm{~Hz}, \delta_{\mathrm{C}} 101.7,101.8$ and $\delta_{\mathrm{H}}$ $6.25,6.27$, each $\left.d, 2.0 \mathrm{~Hz}, \delta_{\mathrm{C}} 112.5,112.6\right)$, four pairs of substituted aromatic carbons $\left(\delta_{\mathrm{C}} 105.1\right.$, $105.2,144.6,144.7,163.6,163.7,166.2,166.5)$, one pair of carboxyl carbon $\left(\delta_{\mathrm{C}} 171.9,172.4\right)$ attributable to two orsellinyl units $\left(2 \mathrm{x}_{8} \mathrm{H}_{7} \mathrm{O}_{3}\right)$ and signals of one butanetetraol unit, including two $s p^{3}$ oxygenated methylenes, $\mathrm{CH}_{2}-1\left(\delta_{\mathrm{H}} 4.91, d d, 12.3,2.7 \mathrm{~Hz}, \mathrm{H}-1 \mathrm{a} ; \delta_{\mathrm{H}} 4.74, d d, 12.3,6.9 \mathrm{~Hz}, \mathrm{H}-1 \mathrm{~b}\right.$; $\left.\delta_{\mathrm{C}} 64.6\right)$ and $\mathrm{CH}_{2}-4\left(\delta_{\mathrm{H}} 3.79, m, \mathrm{H}-4 \mathrm{a} ; \delta_{\mathrm{H}} 3.72, m, \mathrm{H}-4 \mathrm{~b} ; \delta_{\mathrm{C}} 64.0\right)$ and two $s p^{3}$ oxygenated methines, CH-2 $\left(\delta_{\mathrm{H}} 5.68, d d d, 7.2,6.3,2.4 \mathrm{~Hz} ; \delta_{\mathrm{C}} 74.1\right)$ and $\mathrm{CH}-3\left(\delta_{\mathrm{H}} 4.13, m ; \delta_{\mathrm{C}} 71.8\right)$.

These chemical features were reminiscent of those of (+)-D-montagnetol (6) except for the presence of one more orsellinyl unit. This supplementary core was confirmed by the HRESIMS analysis of 1 displaying one more $\mathrm{C}_{8} \mathrm{H}_{7} \mathrm{O}_{3}$ unit than that of $\mathbf{6}$. The signals of the two orsellinyl units were similar and interchangeable but they could be partly distinguished by the NOESY spectrum (Figs. 2, S15), with cross peaks between $\mathrm{H}_{3}-8^{\prime \prime}\left(\delta_{\mathrm{H}} 2.41\right)$ with $\mathrm{H}-3$ and $\mathrm{H}-5$ " as well as $\mathrm{H}_{3}-8^{\prime}$ with $\mathrm{H}-$ $5^{\prime}$. The downfield methine H-2 $\left(\delta_{\mathrm{H}} 5.68\right)$ and H-3 signals $\left(\delta_{\mathrm{H}} 4.13\right)$ compared to those of $6\left[\delta_{\mathrm{H}} 4.00\right.$ $(\mathrm{H}-2)$ and $3.72(\mathrm{H}-3)$ ] suggested the position at C-2 of the second orsellinyl unit. This attachment was further confirmed by the HMBC correlations of H-2 to C-7" $\left(\delta_{\mathrm{C}} 171.9\right)$ and of $\mathrm{H}-1\left(\delta_{\mathrm{H}} 4.91\right.$ and 4.74) to $\mathrm{C}-7^{\prime}\left(\delta_{\mathrm{C}} 172.4\right)$. Therefore, the planar structure of 1 could be established as 1,2-di-(2,4dihydroxy-6-methylbenzoyloxy)-3,4-dihydroxybutane (Fig. 1). The absolute configurations of C-2 and C-3 of 1 were suggested to be $(2 R, 3 S)$ as in (+)-montagnetol $(6)$ or $(+)$-erythrin $(8)$ owing to both the compatibility of the positive specific rotation and the coupling constants of the butanetetraol moiety of these compounds (Basset et al., 2010). This assignment was further supported applying the modified Mosher method (Hoye et al., 2007). For this purpose, compound 1 was treated with $(R)$ - and $(S)$-2-methoxy-2-trifluoromethyl-2-phenylacetyl chloride (MTPA-Cl) to afford the $(S)$ - and $(R)$-MTPA esters ( $\mathbf{S}$ and $\mathbf{1} \boldsymbol{R}$, respectively) for subsequent ${ }^{1} \mathrm{H}$ NMR data analysis. Compound 1 possessed one secondary [C(3)] and one primary [C(4)] alcohol groups but just only the latter group was esterified as indicated by the NMR chemical shifts (Fig. 3). The absolute configuration at C-3 of 1 was elucidated on the basis of differences of ${ }^{1} \mathrm{H}$ chemical shifts and signal patterns of two geminal protons of the methylene protons attached to the ester linkage in the MTPA-derivative, at C-4 of $\mathbf{1 S}$ and $\mathbf{1 R}$ in this specific example. It was indeed demonstrated that the absolute configuration of a branched group at $\beta$-position of primary alcohols could be determined through a modified Mosher method as reported by Tsuda and co-workers (Tsuda et al., 
Table 1 NMR spectroscopic data of compounds 1-4

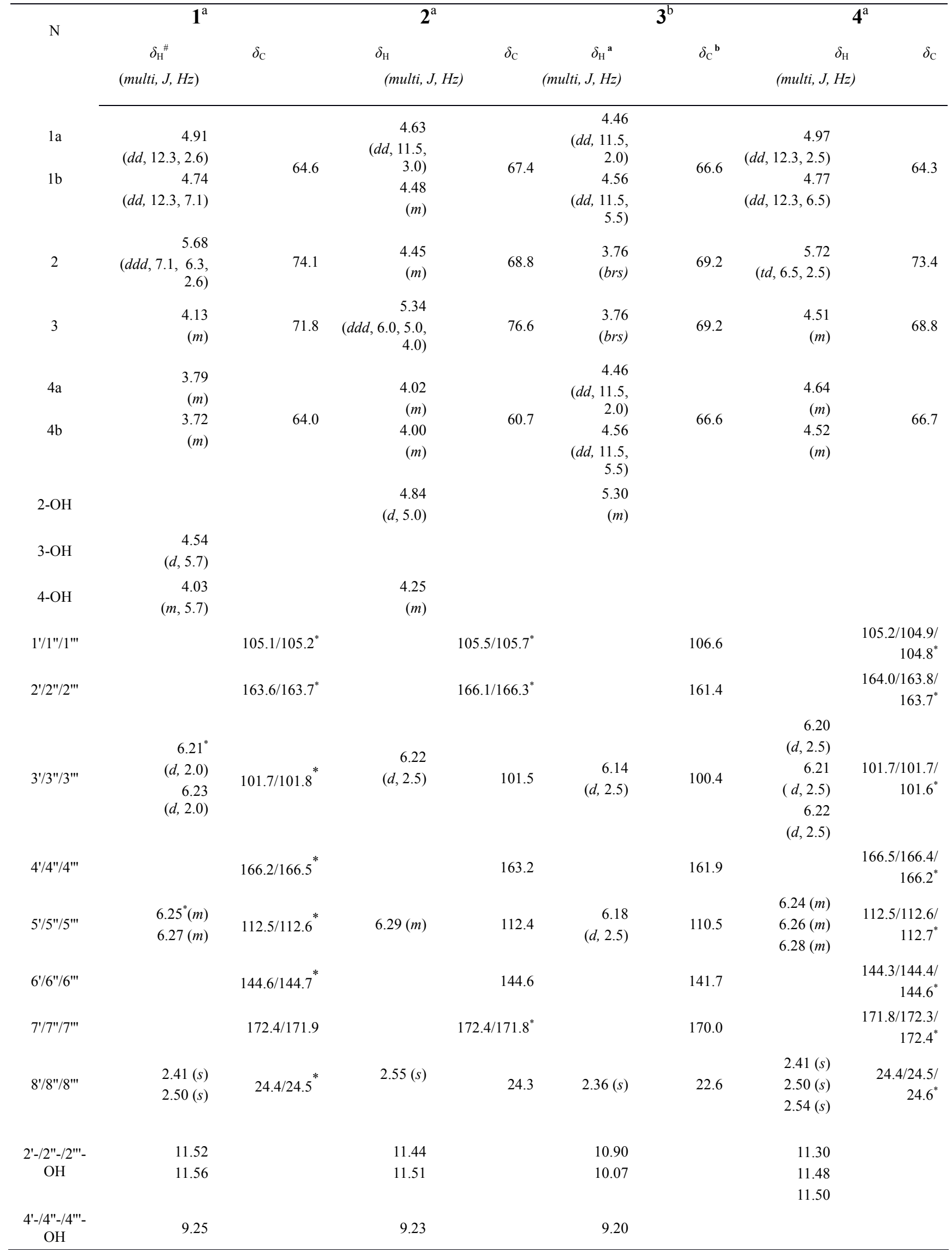

All spectra were recorded ${ }^{\mathrm{a}}$ in acetone- $d_{6} ;{ }^{\mathrm{b}}$ in DMSO- $d_{6} ;{ }^{\#}$ : recorded at $300 \mathrm{MHz} ;{ }^{*}$ Values in each line or column (of each compound) could be interchanged 
2003). Following this scheme, in the ${ }^{1} \mathrm{H}$ NMR spectra of the $(+)-(R)-$ MTPA ester, two methylene protons adjacent to the studied asymmetric carbon were observed as separated double doublet signals $\left[\Delta \delta\left(\delta_{\text {low }}-\delta_{\text {high }}\right)\right.$ ca. 0.23$]$, while the corresponding ones of (-)-(S)-MTPA ester were close to each other $(\Delta \delta$ 0.03) or overlapped indicating the absolute configuration of the asymmetric carbon was $R$. In the case of 1 , signals of the two methylene protons $\mathrm{H}_{2}-4$ of $1 S$ and $1 R$ were in agreement with an $S$ configuration for C-3 (Tsuda et al., 2003). Consequently, 1 was characterized as $\quad(2 R, 3 S)$-1,2-di-(2,4-dihydroxy-6-methylbenzoyloxy)-3,4-dihydroxybutane or orsellinylmontagnetol A.

Compound 2 was obtained as a white amorphous powder. The ${ }^{13} \mathrm{C}$ NMR and HRESIMS data established a molecular formula of $\mathrm{C}_{20} \mathrm{H}_{22} \mathrm{O}_{10}$. The identical molecular formula as well as the same types of hydrogens and carbons of $\mathbf{2}$ and $\mathbf{1}$ (Table 1) revealed that the former was also composed of two orsellinyl units and one butanetetraol unit. The downfield chemical shift of $\mathrm{H}-3\left(\delta_{\mathrm{H}} 5.34\right)$ compared to the corresponding one of 1 suggested that the position of the second orsellinyl unit was at C-3. This assumption was further strengthened by the HMBC cross-peaks between H-3 to the carbinol carbon $\mathrm{C}-2\left(\delta_{\mathrm{C}} 68.8\right)$ as well as to the carbonyl carbon C-7" $\left(\delta_{\mathrm{C}} 171.8\right)$ of this second orsellinyl unit. The complete analysis of the HSQC and HMBC data (Fig. 2) for 2 supported its planar structure as shown in Fig. 1. The coupling constants of protons of the butanetetraol moiety of 2 especially of $\mathrm{H}-1 \mathrm{a}(d d, 11.5,3.0 \mathrm{~Hz})$ and $\mathrm{H}-3(d d d, 6.0,5.0,4.0 \mathrm{~Hz})$ were of the same magnitude with those of $\mathbf{1}$ suggesting that the relative configuration of $\mathbf{2}$ was similar to that of $\mathbf{1}$.

Compound 2 was also treated with $(R)$ - and $(S)$-MTPA-Cl to afford the $(S)$ - and $(R)$-MTPA esters ( $\mathbf{S}$ and $\mathbf{2} \boldsymbol{R}$, respectively). As for $\mathbf{1}$, only the primary [(C-4)] alcohol group of compound $\mathbf{2}$ was esterified and the structures of these esters were elucidated on the basis of their ${ }^{1} \mathrm{H}$ NMR and COSY spectral data analysis (Figs. S26 and S27). Proton signal patterns of $\mathrm{H}_{2}-4$ of $(S)$ - and $(R)$ MTPA esters ( $\mathbf{2} S$ and $\mathbf{2} \boldsymbol{R}$, respectively) were similar to those of $\mathbf{1}$ (Fig. 3) suggesting the $S$ absolute configuration for $\mathrm{C}-3$ of $\mathbf{2}$. Therefore, the absolute configurations $(2 R, 3 S)$ were attributed for $\mathbf{2}$ as in 1 due to the compatibility of the positive optical rotation, the coupling constants as well as biogenetic considerations. Accordingly, compound $\mathbf{2}$ was identified as (2R,3S)-1,3-di-(2,4dihydroxy-6-methylbenzoyloxy)-2,4-dihydroxybutane or orsellinylmontagnetol B.

Tsuda and co-workers stated that the method might be not suitable for compounds without a methyl group at position C-2 or a consecutive chiral center at C-3 (Tsuda et al., 2003). Since 1 and 2 both lack such a C-2 methyl group and display a consecutive chiral center, the method described by Tsuda does not seem relevant to establish their stereochemistry. However, these limitations do not stand longer with regard to the former publication of this strategy (Yasuhara et al., 1986) and further applications to various chemical scaffolds including MTPA esters of furan derivatives (Kubota et al., 2002), scalusamide (Tsuda et al., 2005), and cycloartanes (Wang et al., 2014) (see Fig. S1). 
Analysis of the $\Delta \delta_{\mathrm{x}, \mathrm{y}}$ values (see Fig. S1) of two geminal protons of two MTPA esters of these mentioned compounds revealed similar results of the Tsuda's method applied to compounds possessing the methyl group at the $\beta$-position. Furthermore, calculation of the $\Delta \delta_{S, R}$ values of MTPA esters of 1 and $\mathbf{2}$ gave similar values with a negative one for $\mathrm{H}-3$ and positive ones for $\mathrm{H}_{2}-1$ and $\mathrm{H}$ 2, suggesting that both of them have the same stereochemistry at C-2 and C-3 (see Fig. S2). Due to biosynthetic considerations, the absolute configuration of $\mathbf{1}$ and $\mathbf{2}$ were strongly supported.

Compound $\mathbf{3}$ was isolated as a white amorphous powder. Its molecular formula was determined as $\mathrm{C}_{20} \mathrm{H}_{22} \mathrm{O}_{10}$ through the pseudomolecular ion peak at $m / z 445.1127[\mathrm{M}+\mathrm{Na}]^{+}$in the HRESIMS spectrum. Compound $\mathbf{3}$ possessed the same molecular formula as $\mathbf{1}$ and $\mathbf{2}$, but its ${ }^{13} \mathrm{C}$ NMR spectrum only revealed a half of the carbon signals comparing to those of the two latters. Signals corresponding to the orsellinyl and butanetetraol units in the ${ }^{1} \mathrm{H}$ NMR and HSQC spectra were also simpler especially in the zone from 3.7 to $5 \mathrm{ppm}$ suggesting the symmetrical structure of 3. Based on the fact that $\mathbf{3}$ was optically inactive and was isolated from the same biosource, its stereochemistry was supposed to be similar with those of $\mathbf{1}$ and $\mathbf{2}$ while the configuration of $2 R, 3 R$ or $2 S, 3 S$ of $\mathbf{3}$ resulted in its optical activity which was not compatible to that of $\mathbf{3}$. Complete analysis of the 2D NMR data for 3 resulted in its formulation as $(2 R, 3 S)$-1,4-di-(2,4-dihydroxy-6methylbenzoyloxy)-2,3-dihydroxybutane and was named orsellinylmontagnetol C.

Compound 4 was isolated as a white amorphous powder and the molecular formula was established to be $\mathrm{C}_{28} \mathrm{H}_{28} \mathrm{O}_{13}$ based on HRESIMS data suggesting one more $\mathrm{C}_{8} \mathrm{H}_{7} \mathrm{O}_{3}$ unit than 1-3. Indeed, the ${ }^{1} \mathrm{H}$ and ${ }^{13} \mathrm{C}$ NMR spectra of 4 revealed the occurrence of three orsellinyl units with three methyl signals $\left(\delta_{\mathrm{H}} 2.41,2.50\right.$ and 2.54; $\delta_{\mathrm{C}} 24.4,24.5$ and 24.6), and sets of three aromatic proton or carbon signals (Table 1). Detailed comparison of NMR spectroscopic data of $\mathbf{4}$ with those of $\mathbf{3}$ showed a downfield ${ }^{1} \mathrm{H}$ NMR chemical shift value of $\mathrm{H}_{2}-2\left(\delta_{\mathrm{H}} 5.72, \delta_{\mathrm{C}} 73.4\right.$ in 4 versus $\delta_{\mathrm{H}} 3.76, \delta_{\mathrm{C}}$ 69.2 in 3) proving unambiguously the attachment of the third orsellinyl unit at C-2. Additionally, HMBC cross-peaks of $\mathrm{H}_{2}-1\left(\delta_{\mathrm{H}} 4.77\right.$ and 4.97$)$, of $\mathrm{H}-2\left(\delta_{\mathrm{H}} 5.72\right)$ and of $\mathrm{H}_{2}-4\left(\delta_{\mathrm{H}} 4.52\right.$ and 4.64$)$ to carboxyl carbon signals in the chemical shifts range 171-173 ppm suggested that each of these three carbons were linked to an orsellinyl unit. The NOESY experiment also supported these connections with the correlations of $\mathrm{H}-2$ with $\mathrm{H}_{3}-8$ ", and of $\mathrm{H}-4$ with $\mathrm{H}_{3}-8^{\prime \prime \prime}$ (Fig. 2). The absolute configuration at C-2 and C-3 of $\mathbf{4}$ was proposed to be $(2 R, 3 S)$ as in $\mathbf{1}-\mathbf{3}$ due to the positive optical rotation, the coupling constants of carbinol protons and to biosynthetic considerations as well. However, the optical rotation data appeared close to zero suggesting that $\mathbf{4}$ might represent a nearly 1:1 mixture of enantiomers (i.e (2R,3S)- and (2S,3R)-1,2,4-tri-(2,4-dihydroxy-6methylbenzoyloxy)-3-hydroxybutane)) and was named orsellinylmontagnetol D. 
Compound $\mathbf{5}$ was isolated as a white amorphous powder. The molecular formula of $\mathbf{5}$ was determined to be $\mathrm{C}_{12} \mathrm{H}_{14} \mathrm{O}_{6}$ using HRESIMS. The ${ }^{1} \mathrm{H}-,{ }^{13} \mathrm{C}$ NMR as well as HSQC data revealed one aromatic methyl group $\mathrm{CH}_{3}-8^{\prime}\left(\delta_{\mathrm{H}} 2.50, \delta_{\mathrm{C}} 24.2\right)$ and two meta-coupled methines, $\mathrm{CH}-3^{\prime}\left(\delta_{\mathrm{H}} 6.23, d\right.$, $\left.2.0 \mathrm{~Hz} ; \delta_{\mathrm{C}} 101.6\right)$ and $\mathrm{CH}-5{ }^{\prime}\left(\delta_{\mathrm{H}} 6.27, d, 2.0 \mathrm{~Hz} ; \delta_{\mathrm{C}} 112.3\right)$, attributable to one orsellinyl unit $\left(\mathrm{C}_{8} \mathrm{H}_{7} \mathrm{O}_{3}\right)$ and the signals of one butanetetraol unit, including two $s p^{3}$ oxygenated methylenes, $\mathrm{CH}_{2}-$ $1\left(\delta_{\mathrm{H}} 4.10, d d, 10.0,5.5 \mathrm{~Hz}, \mathrm{H}-1 \mathrm{a} ; \delta_{\mathrm{H}} 3.94, d d, 10.0,4.0 \mathrm{~Hz}, \mathrm{H}-1 \mathrm{~b} ; \delta_{\mathrm{C}} 70.9\right)$ and $\mathrm{CH}_{2}-4\left(\delta_{\mathrm{H}} 4.00, d d\right.$, 9.0, 6.0 Hz, H-4a; $\left.\delta_{\mathrm{H}} 3.70, d d, 9.0,6.0 \mathrm{~Hz}, \mathrm{H}-4 \mathrm{~b} ; \delta_{\mathrm{C}} 72.7\right)$ and two $s p^{3}$ oxygenated methines, $\mathrm{CH}-2$ $\left(\delta_{\mathrm{H}} 5.45, d d d, 5.5,5.5,4.0 \mathrm{~Hz} ; \delta_{\mathrm{C}} 75.4\right)$ and $\mathrm{CH}-3\left(\delta_{\mathrm{H}} 4.59, d d d, 6.0,6.0,5.5 \mathrm{~Hz} ; \delta_{\mathrm{C}} 71.0\right)$. These chemical features were similar to those of (+)-D-montagnetol (6). The downfield methine H-2 indicated the attachment of the orsellinyl unit at C-2 which was further confirmed by the HMBC cross-peak of H-2 to C-7'. A suitable candidate that fit the NMR data and especially the HRMS data of 5 possessing one more unsaturated degree and one less water unit than that of $\mathbf{6}$ would be the ring-closure between two hydroxy groups to yield a five-membered ring as shown in Fig. 1. This proposed structure was supported by HMBC cross-peaks between proton H-1 to C-4 and vice versa (Fig. 4). Consequently, the planar structure of $\mathbf{5}$ was deduced as shown in Fig. 1 with a carbon numbering in accordance to the biogenetic origin discussed below.

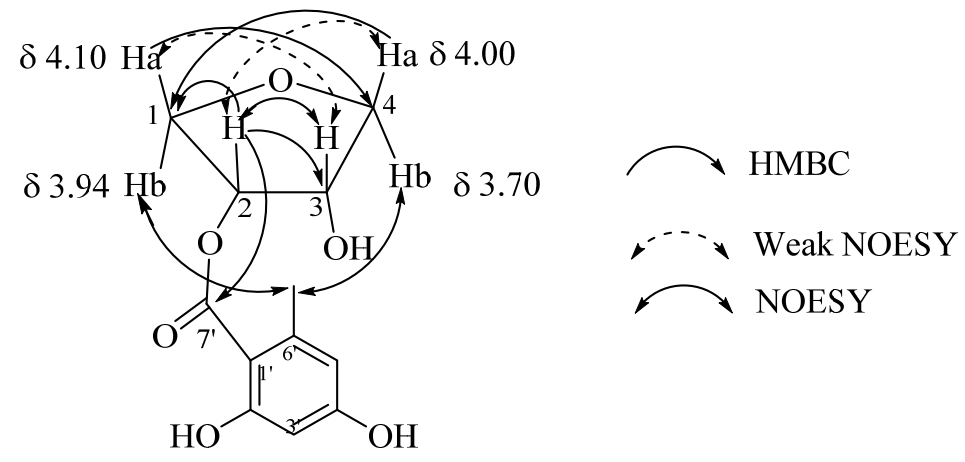

Fig. 4. Key HMBC and NOESY correlations of compound 5.

The relative stereochemistry of $\mathbf{5}$ was determined by the NOESY correlations. Protons $\mathrm{H}-1 \mathrm{~b}$ $\left(\delta_{\mathrm{H}} 3.94\right), \mathrm{H}-4 \mathrm{~b}\left(\delta_{\mathrm{H}} 3.70\right)$ and the aromatic methyl 6'- $\mathrm{CH}_{3}$ showed NOE correlation to each other indicating that they were synfacial. This led to the $s y n$ positions of $\mathrm{H}-1 \mathrm{a}\left(\delta_{\mathrm{H}} 4.10\right)$ and $\mathrm{H}-4 \mathrm{a}\left(\delta_{\mathrm{H}}\right.$ 4.00). Moreover, H-2 $\left(\delta_{\mathrm{H}} 5.45\right)$ and H-3 $\left(\delta_{\mathrm{H}} 4.59\right)$ showed weak NOESY correlations with H-4a and H-1a, respectively (see Fig. S51). In other words, these four protons were in the same orientation, implying that the two oxygenated groups, 2-O-benzoyl and 3-OH, were synfacial (Fig. 4). Thus, compound 5 could correspond to either (2R,3S)- or (2S,3R)-2-(2,4-dihydroxy-6-methylbenzoyloxy)3-hydroxytetrahydrofuran. Interestingly, the two hydrogens $\mathrm{H}-1 \mathrm{~b}\left(\delta_{\mathrm{H}} 3.94\right)$ and $\mathrm{H}-4 \mathrm{~b}\left(\delta_{\mathrm{H}} 3.70\right)$ were up-field shifted compared to hydrogens $\mathrm{H}-1 \mathrm{a}\left(\delta_{\mathrm{H}} 4.10\right)$ and $\mathrm{H}-4 \mathrm{a}\left(\delta_{\mathrm{H}} 4.00\right)$ supporting that $\mathrm{H}-1 \mathrm{~b}$ and 
$\mathrm{H}-4 \mathrm{~b}$ are synfacial to the two oxygenated groups, 2-O-benzoyl and 3-OH, respectively. Effects of substituents on ${ }^{1} \mathrm{H}$ chemical shifts of non-equivalent methylene protons in some tetrahydrofuran derivatives were reported (Mihelich and Hite, 1992; Brovetto and Seoane, 2008; Yoshimatsu et al., 1996; Williams et al., 1984) (see Fig. S3).

Compound 5 was also treated with $(R)$ - and $(S)$-MTPA-Cl to afford the $(S)$ - and $(R)$-MTPA esters ( $\mathbf{5} \boldsymbol{S}$ and $\mathbf{5} \boldsymbol{R}$, respectively). Surprisingly, the ${ }^{1} \mathrm{H}$ NMR spectrum of $\mathbf{5} \boldsymbol{S}$ (Fig. S42) revealed that some signals appeared in pair with a ratio of approximately 1:1 based on the integration of all proton signals including two chelated hydroxy groups $\left(\delta_{\mathrm{H}} 11.27,11.10\right)$, signals of four MTPA phenyl units at $\delta_{\mathrm{H}} 7.70-7.12$, four aromatic protons $\left(\delta_{\mathrm{H}} 6.65,6.59,6.40,6.37\right)$, signals of two butanetetraol units at $\delta_{\mathrm{H}} 5.60-3.70$, four MTPA methoxy groups $\left(\delta_{\mathrm{H}} 3.69,3.68,3.52,3.37\right)$ and two aromatic methyl group $\left(\delta_{\mathrm{H}} 2.26\right)$.

The comparison of ${ }^{1} \mathrm{H}$ NMR data of $\mathbf{5}$ and $\mathbf{5 S}$ (Fig. S54) measured in the same deuterated solvent $\mathrm{CDCl}_{3}$, revealed that protons $\mathrm{H}-3, \mathrm{H}-3^{\prime}$ and $\mathrm{H}-5^{\prime}$ of the latter were down-field shifted compared to the corresponding ones of the former suggesting that the two hydroxy groups (( $3-\mathrm{OH}$ and $\left.4^{\prime}-\mathrm{OH}\right)$ of $\mathbf{5 S}$ were MTPA esterified. A suitable explanation for these NMR signals was that $\mathbf{5 S}$ corresponded to a mixture of two regio isomers, (2R,3S,2-S-MTPA,4'-S-MTPA) and (2R,3S,3-SMTPA,4'-S-MTPA) leading to the identification of 5 as a mixture of $(2 R, 3 S)$ - 2-(2,4-dihydroxy-6methylbenzoyloxy)-3-hydroxytetrahydrofuran and (2R,3S)-3-(2,4-dihydroxy-6-methylbenzoyloxy)2-hydroxytetrahydrofuran, with the ratio of roughly 1:1. While it might seem strange not having detected the 3-O-orsellinyl-tetrahydrofurandiol derivative throughout the extensive NMR spectra acquired from 5, it is worth emphasizing that the tetrahydrofuran-2,3-diol represents a meso moiety. Therefore, the compounds related to 2-O-orsellinyltetrahydrofurandiol and those related to 3-Oorsellinyltetrahydrofurandiol enter either diastereomeric or enantiomeric relationships. As to the two components described in $\mathbf{5}$, they indeed represent two enantiomers. The non-null specific optical rotation might be explained by the slight enantiomeric excess observed in NMR. The ${ }^{1} \mathrm{H}$ NMR spectrum of $\mathbf{5} \boldsymbol{R}$ contained much more crowded signals compared to those of $\mathbf{5} \boldsymbol{S}$. However, among them, there were some signals somewhat similar to those of $\mathbf{5 S}$. Most likely due to an excessive usage of MTPA-Cl and pyridine, other hydroxy groups in $\mathbf{5}$ were also MTPA esterified besides the two target alcohol groups (3-OH and 4'-OH), forming more diastereomers. Finally, compound 5 was elucidated as shown and was named hydrofurylmontagnetol.

The relative configuration of its two chiral centers $\mathrm{C}-2$ and $\mathrm{C} 3$ are conserved as $(2 R, 3 S)$ [or $(2 S, 3 R)]$ similar to D-montagnetol (6) or other montagnetol derivatives (1-4) suggesting that they have a close relationship. Indeed, 5 could be obtained from 6 via a transesterification prior to its dehydration. Such reactions were already reported to occur in lichens (Duong et al., 2015). 
Likewise, Lobaria scrobiculata contained para-scrobiculin and meta-scrobiculin, the former being the transesterified product of the latter, or vice versa (Elix and Gaul, 1986). A similar cyclodehydration converting erythritol to a tetrahydrofuran was described and granted a similar stereochemistry (Pavlik et al., 2009). The quick transesterification between the two enantiomers in the latter stage was reported (Muller et al., 2009). The putative transformation from $\mathbf{6}$ to $\mathbf{5}$ is presented in Scheme 1.

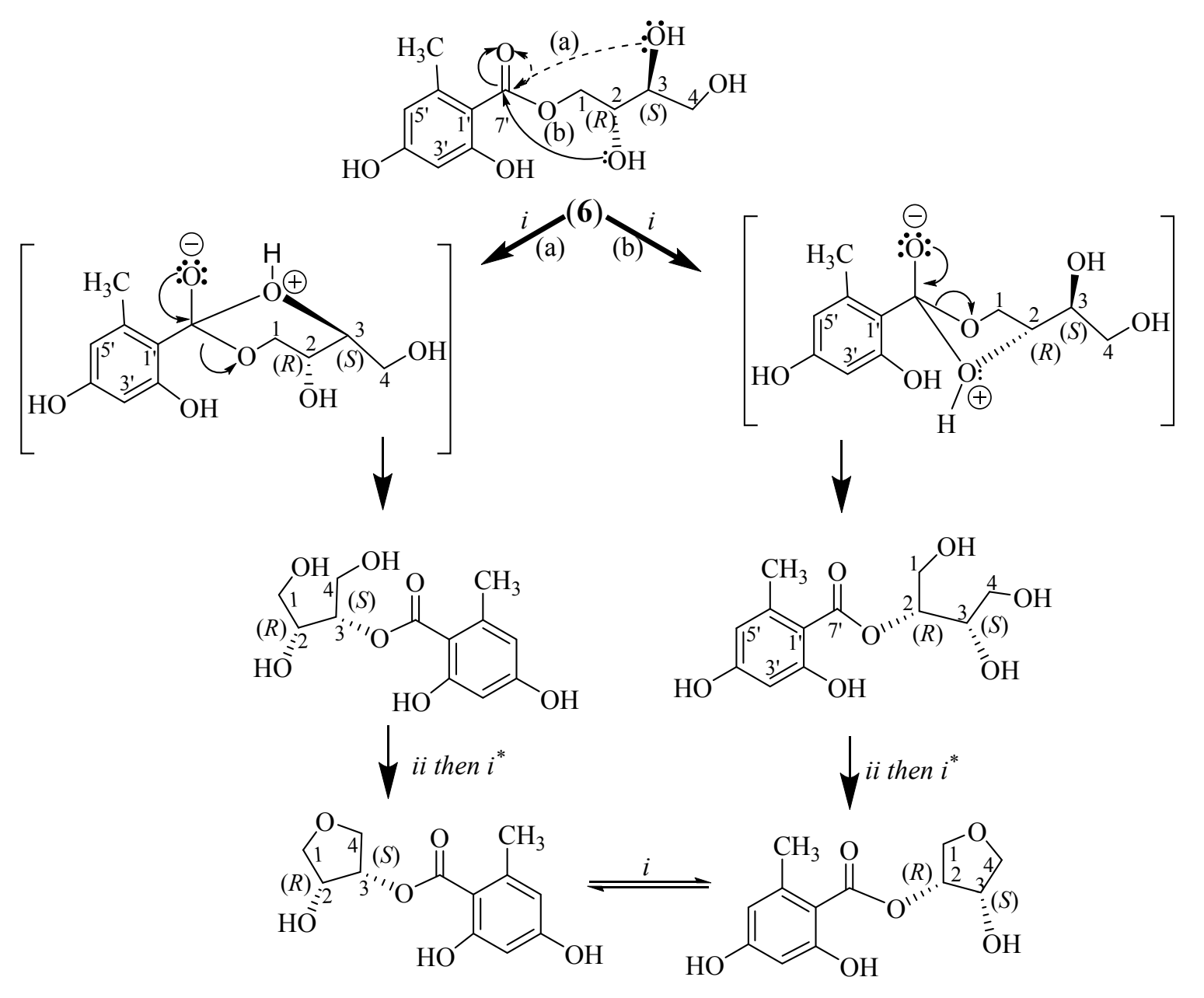

(5)

Scheme 1: The proposed biosynthetic pathway for the formation of compound 5 from D-montagnetol (6). [(i): transesterification; (ii): cyclodehydration]. * or vice versa

As a polyol, erythritol is assumed to be produced by the photobiont partner (Nash, 2008). This polyol is substituting lecanoric acid and orsellinic acid to afford large amounts of erythrin and Dmontagnetol, respectively, in Roccella lichens. The minute amounts of orsellinylmontagnetols A-D derivatives complicated their detection but orsellinylmontagnetols A (1), B (2) and C (3) could be characterized in a $R$. montagnei acetone extract by HPLC-DAD (Figs. S5-S6). Other new derivatives were visualized in TLC from fractions obtained from the initial methanol extract (Fig. 
S4) suggesting their native occurrence. The unusual acetylerythritol (7) is thought to be a direct derivative of the known polyol to be produced by many Trentepohliaceae algae (Feige and Kremer, 1980). Erythritol has been shown to be transferred in large quantities from the photobiont to the mycobiont in intact Roccella lichens and serves as the main transfer substance from the primary producer to its heterotrophic partner in this specific type of the lichen symbiosis (Richardson et al., 1968). Although erythritol has been shown to be fully biosynthesized by non lichenised fungi (Ingavat et al., 2009), it is unlikely that this substance is directly synthesized by a mycobiont in the specific circumstances of a lichen symbiosis with a Trentepohlia photobiont with its abundant presence of erythritol pool coming from the photobiont. The source of the derivative acetylerythritol instead remains to be elucidated in further detail. While it is supposed to arise from a modification of erythritol by the fungus, a metabolism switch in the Trentepohlia strain cannot be fully excluded. The stability of this polyol in methanol, and the absence of the acetylerythritol formation in reproducing the purification process support its genuine lichen production.

Despite the rather large quantity (dozens of $\mathrm{mg}$ ) of new compounds purified in the course of this study, the fact that they were not formerly described in Roccella species might be explained by the unusually large amount of lichen material investigated here. Such new compounds might correspond to previously visualized metabolites (Tehler, 2010) whose identification was so far precluded due to shortage of material. A conclusive evidence for the presence of genuine compounds in lichens could be given by a direct analysis of the lichen thallus, using for instance the recently described DART-MS tool performed from unprocessed lichen material and therefore by passing the artifacts associated with extraction and purification procedures (Le Pogam et al., 2015; 2016). Likewise, emerging Mass Spectroscopy Imaging techniques might provide very informative data about the location of lichen metabolites. Such work is ongoing with tropical Roccella species as some studies revealed the spatial metabolite profiling on briton Roccella species (Parrot et al., 2015). Additional minor compounds have also to be identified from this lichen and to be discussed for their chemotaxonomic significance along with assays for their bioactivities.

In this study, compounds $\mathbf{1}, \mathbf{3}, \mathbf{5}, \mathbf{6}$, and $\mathbf{8}$ were tested at a concentration of $100 \mu \mathrm{g} / \mathrm{mL}$ for their cytotoxicity against MCF-7 (breast cancer cell line), HepG2 (liver hepatocellular carcinoma), NCI-H460 (lung cancer cell line), and HeLa (human epithelial cancer) cell lines, using the Sulforhodamine B (SRB) method (Skehan et al., 1990) (Tables S1, S2). Only compound 1 exhibited moderate activity against MCF-7 cell line with the $\mathrm{IC}_{50}$ value $(\mu \mathrm{M})$ of $68.39 \pm 3.46 \mu \mathrm{M}$ whilst it showed no activities against NCI-H460 and HeLa cell lines. Other compounds were found inactive.

\section{Experimental}




\subsection{General experimental procedures}

The NMR spectra were measured on a Bruker Avance III $\left(500 \mathrm{MHz}\right.$ for ${ }^{1} \mathrm{H}$ NMR and 125 $\mathrm{MHz}$ for ${ }^{13} \mathrm{C}$ NMR), Varian Mercury-400 Plus NMR (400 MHz for ${ }^{1} \mathrm{H}$ NMR and $100 \mathrm{MHz}$ for ${ }^{13} \mathrm{C}$ NMR), Bruker 300 (300 MHz for ${ }^{1} \mathrm{H}$ NMR) spectrometers. Proton chemical shifts were referenced to the solvent residual signal of $\mathrm{CD}_{3} \mathrm{COCD}_{3}$ at $\delta_{\mathrm{H}} 2.05$ and of $\mathrm{CD}_{3} \mathrm{SOCD}_{3}$ at $\delta_{\mathrm{H}} 2.50$. The ${ }^{13} \mathrm{C}$ NMR spectra were referenced to the central peak of $\mathrm{CD}_{3} \mathrm{COCD}_{3}$ at $\delta_{\mathrm{C}} 29.4$ and of $\mathrm{CD}_{3} \mathrm{SOCD}_{3}$ at $\delta_{\mathrm{C}} 39.5$. The HR-ESI-MS were recorded on a Bruker micrOTOF Q-II. TLC was carried out on pre-coated silica gel $60 \mathrm{~F}_{254}$ or silica gel $60 \mathrm{RP}-18 \mathrm{~F}_{254} \mathrm{~S}$ (Merck) and spots were visualized by spraying with $10 \% \mathrm{H}_{2} \mathrm{SO}_{4}$ solution followed by heating. The optical rotations were measured on a Jasco DIP-370 digital polarimeter. The IR spectra were measured on a Shimadzu FTIR-8200 infrared spectrophotometer. The UV spectra were measured on a Perkin Elmer Lambda 25 UV-Vis spectrometer. Gravity column chromatography was performed with silica gel $60(0.040-0.063 \mathrm{~mm}$, Himedia). HPLC-DAD Shimadzu LC-20AD using a Kinetex C18 HPLC column $(2.6 \mu \mathrm{m}, 100 \times 4.6$ $\mathrm{mm}$, Phenomenex) was coupled with the quadrupole ESI MS analyzer (Advion, U.S.A).

\subsection{Lichen material}

Thalli of the studied lichen were separated from the bark of various trees at Co Thach pagoda, Tuy Phong district, Binh Thuan province in August-September 2012. The geographical location of Co Thach pagoda where the lichen was collected is at an altitude of 64 meters, near the sea (around 100 meters), $11^{\circ} 11^{\prime} 43^{\prime \prime} \mathrm{N}$ and $107^{\circ} 31^{\prime} 34^{\prime \prime} \mathrm{E}$, Vietnam. Random thalli from the sorted out material were identified as the fertile form of Roccella montagnei by Dr. Holger Thüs. A voucher specimen (No US-B024) was deposited in the herbarium of the Department of Organic Chemistry, University of Science, Ho Chi Minh City.

\subsection{Extraction and isolation}

The clean, air-dried and ground material $(1.7 \mathrm{~kg})$ was extracted by maceration with methanol at ambient temperature and the filtrated solution was concentrated in vacuo to obtain the crude extract (450 g). This crude extract was applied to normal phase silica gel column chromatography, and eluted with a solvent system of $n$-hexane: ethyl acetate (H:EA) (stepwise, 10:0 to 0:10) to afford fractions, H (10.2 g), EA1 (21.1 g), EA2 (66.1 g), EA3 (29.8 g), and EA4 (64.2 g). The remaining was eluted with methanol to give the methanol extract $\mathbf{M}(50.4 \mathrm{~g})$.

The fraction EA1 (21.1 g) was applied to silica gel column chromatography to be eluted stepwise with $n$-hexane: ethyl acetate: acetic acid (H:EA:AcOH, stepwise, 9:1:0.02-0:10:0.02) to grant three sub-fractions EA1.1 (2.8 g), EA1.2 (15.1 g) and EA1.3 (1.1 g). Sub-fraction EA1.1 was fractionated with H:EA:AcOH (9:1:0.05) to afford three fractions, EA1.1.1 (298.8 mg), EA1.1.2 
(1.2 g) and EA1.1.3 (0.9 g). A part of fraction EA1.1.2 (300 mg) was rechromatographed using $\mathrm{H}: \mathrm{EA}: \mathrm{AcOH}$ (9:1:0.04), then applied to preparative TLC to afford two compounds, 3 (14.8 $\mathrm{mg}$ ) and 12 (199.5 mg). Fraction EA1.1.3 was also rechromatographed eluting with H:EA:AcOH (9:1:0.04), then applied to preparative TLC to yield 11 (295.7 $\mathrm{mg})$. Fraction EA1.2 (15.1 g) was rechromatographed, eluting with chloroform: ethyl acetate: acetone (C:EA:Ac, 9:1:3) to obtain three fractions EA1.2.1 (0.3 g), EA1.2.2 (3.4 g) and EA1.2.3 (9.9 g). Fraction EA1.2.1 was applied repeatedly to preparative TLC, eluting with C:EA:Ac:AcOH (9:1:3:0.02) to afford two compounds, $2(6.1 \mathrm{mg})$ and 4 (7.8 $\mathrm{mg})$. Fraction EA1.2.2 (3.4 g) was further chromatographed by CC to obtain two major compounds, $6(1.5 \mathrm{~g}), \mathbf{8}(1.0 \mathrm{~g})$, and the remaining. This residue was applied to preparative TLC, eluted with C:EA:Ac:AcOH (9:1:3:0.02) to purify two compounds, 1 (13.1 mg) and $5(20.2 \mathrm{mg})$. The fraction EA2 $(66.1 \mathrm{~g})$ was applied to silica gel column chromatography, eluting with H:EA:AcOH (Stepwise, 9:1:0.02-0:10:0.02) to give two sub-fractions EA2.1 (22.1 g) and EA2.2 (33.9 g). Fraction EA2.1 was rechromatographed, eluting with C:EA:Ac (9:1:3) to afford three fractions EA2.1.1 (8.0 g), EA2.1.2 (2.5 g) and EA2.1.3 (10.2 g). Fraction EA2.1.2 was chromatographed, eluting with C:EA:Ac (9:1:3) to give three compounds 7 (79.7 mg), 9 (30.1 mg), and 10 (9.9 $\mathrm{mg})$.

\section{TLC experiments proving the natural occurrence of compounds 1-5.}

In order to check that the new metabolites were not artifacts of the isolation procedure, the extraction process using acetone was conducted again on a new sample of lichen. A new lichen sample (100 mg) was cut into small pieces and extracted with acetone $(5 \mathrm{~mL})$ or methanol $(5 \mathrm{~mL})$ at ambient temperature for $24 \mathrm{~h}$. Each filtered solution was blown by a fan at room temperature to afford a concentrated solution $(0.5 \mathrm{~mL})$. The acetone extract as well as the EA1 fraction were spotted on an analytical TLC plate and run against acetone solutions of the five new compounds 1-5 using standard solvent systems (Elix, 2014): A (toluene: dioxane: acetic acid, 180: 45: 5), C (toluene: acetic acid, 170: 30), F (cyclohexane : ethyl acetate, 50:50), G (toluene : ethyl acetate : formic acid, 139:83:8), and $H$ (cyclohexane : ethyl acetate : acetic acid, 100:100:50). Spots were visualized by UV prior to spraying the plate with vanillin/5\% aqueous $\mathrm{H}_{2} \mathrm{SO}_{4}$ solution followed by heating.

\section{HPLC experiments proving the natural occurrence of compounds 1-3}

As methanolysis is frequently observed with lichen compounds, an acetone extract of the studied lichen was analyzed through a HPLC-DAD-ESI/MS. Isolated compounds were injected separately. The mobile phase consisted of $\left(\mathrm{H}_{2} \mathrm{O}+0.1 \% \mathrm{HCOOH}\right)$ as solvent $\mathrm{A}$ and $(\mathrm{ACN}+0.1 \%$ $\mathrm{HCOOH}$ ) as solvent $\mathrm{B}$ with the gradient of $20 \%$ to $80 \%$ of $\mathrm{B}$ during $25 \mathrm{~min}, 80 \%$ to $100 \%$ of $\mathrm{B}$ 
during $5 \mathrm{~min}, 100 \%$ of $\mathrm{B}$ during $5 \mathrm{~min}, 100 \%$ to $20 \%$ of B during $5 \mathrm{~min}$. The flow rate was 0.5 $\mathrm{mL} / \mathrm{min}$ and $10 \mu \mathrm{L}$ of each sample was injected. HPLC analysis was conducted on the acetone extract of the lichen and three compounds 1-3. The HPLC chromatogram showed the presence of these compounds (Figs. S5-S6).

Preparation of (S)- and (R)-MTPA Esters of 1.

$(R)-(-)$ and $(S)-(+)-M T P A-C l(6 \mu \mathrm{L})$ and pyridine $(3 \mu \mathrm{L})$ were separately added to two different aliquots of 1 (each $2 \mathrm{mg}$ ) in anhydrous acetone $(200 \mu \mathrm{L})$. The resulting mixtures were allowed to stand at room temperature for 10 days and were monitored everyday by TLC. The products then were separated by preparative TLC to obtain $1 R$ and $1 S .1 S:{ }^{1} \mathrm{H}$ NMR (Acetone- $d_{6}$, $500 \mathrm{MHz}), \delta: 2.41\left(\mathrm{H}_{3}-7 "\right), 2.49\left(\mathrm{H}_{3}-7{ }^{\prime}\right), 3.59$ (MTPA-OC$\left.{ }_{3}\right), 4.51$ (m, H-3), 4.53 (dd, J=11.5, 6.0 Hz, H-4b), 4.73 (dd, J=11.5, 3.5 Hz, H-4a), 4.75 (dd, J=12.5, 6.5 Hz, H-1b), 4.89 (dd, J=12.5, 2.5 Hz, H-1a), 5.59 ( $t d, J=6.5,2.5$ Hz, H-2), 6.22, 6.24 (d, J=2.5 Hz, H-3'/H-3"), 6.26, 6.29 (d, J=2.5 $\left.\mathrm{Hz}, \mathrm{H}-5^{\prime} / \mathrm{H}-5^{\prime \prime}\right), 7.30-7.55$ (5H, $m, \mathrm{Ph}$ of MTPA), $11.42,11.52$ (2'-OH/2"-OH). 1R: ${ }^{1} \mathrm{H}$ NMR (Acetone- $\left.d_{6}, 500 \mathrm{MHz}\right), \delta: 2.41\left(s, \mathrm{H}_{3}-8^{\prime \prime}\right), 2.50\left(s, \mathrm{H}_{3}-8^{\prime}\right), 3.58$ ( $\left.s, \mathrm{MTPA}-\mathrm{OC}_{3}\right), 4.49$ ( $\left.m, \mathrm{H}-3\right)$, 4.59 ( $d d, J=11.5,6.0 \mathrm{~Hz}, \mathrm{H}-4 \mathrm{~b}), 4.66$ ( $d d, J=11.5,3.5 \mathrm{~Hz}, \mathrm{H}-4 \mathrm{a}), 4.69$ (dd, J=12.0, $6.0 \mathrm{~Hz}, \mathrm{H}-1 \mathrm{~b}$ ), 4.89 ( $d d, J=12.0,2.5 \mathrm{~Hz}, \mathrm{H}-1 \mathrm{a}), 5.62$ ( $t d, J=6.5,2.5 \mathrm{~Hz}, \mathrm{H}-2), 6.22,6.24$ ( $\left.d, J=2.5 \mathrm{~Hz}, \mathrm{H}-3^{\prime} / \mathrm{H}-3^{\prime \prime}\right)$, 6.26, $6.28\left(d, J=2.5 \mathrm{~Hz}, \mathrm{H}-5^{\prime} / \mathrm{H}-5^{\prime \prime}\right), 7.30-7.55$ (5H, $\left.m, \mathrm{Ph}\right), 11.42,11.52$ (2'-OH/2"-OH) (Figs. S18-S19).

Preparation of (S)- and (R)-MTPA Esters of 2.

$(R)-(-)$ and $(S)-(+)-M T P A-C l(3 \mu \mathrm{L})$ and pyridine $(1 \mu \mathrm{L})$ were separately added to two different aliquots of $\mathbf{2}$ (each $1 \mathrm{mg}$ ) in anhydrous acetone- $d_{6}$ to obtain $\mathbf{2 S}$ and $\mathbf{2 R}$. The resulting mixtures were allowed to stand at room temperature for 12 days, and then ${ }^{1} \mathrm{H}$ NMR spectra were run without further purification. The related proton signals were assigned by analyzing ${ }^{1} \mathrm{H}-{ }^{1} \mathrm{H}$ COSY spectrum. 2S: ${ }^{1} \mathrm{H}$ NMR (Acetone- $\left.d_{6}, 300 \mathrm{MHz}\right), \delta: 2.41\left(s, \mathrm{H}_{3}-8 "\right), 2.51\left(s, \mathrm{H}_{3}-8^{\prime}\right), 3.58(s$, MTPA-OC $\left.\underline{H}_{3}\right), 4.36$ ( $\left.m, \mathrm{H}-2\right), 4.47$ (dd, $\left.J=12.0,5.4 \mathrm{~Hz}, \mathrm{H}-1 \mathrm{~b}\right), 4.58$ (dd, $\left.J=12.0,3.6 \mathrm{~Hz}, \mathrm{H}-1 \mathrm{a}\right)$, $4.85(d d, J=12.0,2.7 \mathrm{~Hz}, \mathrm{H}-4 \mathrm{~b}), 4.91$ ( $d d, J=12.0,6.0 \mathrm{~Hz}, \mathrm{H}-4 \mathrm{a}), 5.65$ ( $t d, J=6.5,2.5 \mathrm{~Hz}, \mathrm{H}-2)$, 6.29-6.32 (H-3'/H-3"/H-5'/H-5"), 7.30-7.55 (5H, m, Ph of MTPA), 11.42, 11.52 (2'-OH/2"-OH). 2R: ${ }^{1} \mathrm{H}$ NMR (Acetone- $\left.d_{6}, 300 \mathrm{MHz}\right), \delta: 2.34\left(s, \mathrm{H}_{3}-8 "\right), 2.54\left(s, \mathrm{H}_{3}-8\right.$ '), 3.58 ( $\left.s, \mathrm{MTPA}-\mathrm{OCH}_{3}\right)$, 4.44 ( $m, \mathrm{H}-2), 4.48$ ( $m, \mathrm{H}-1 \mathrm{~b}), 4.59$ ( $m, \mathrm{H}-1 \mathrm{a}), 4.88$ ( $m, \mathrm{H}-4 \mathrm{~b}), 4.91$ ( $m, \mathrm{H}-4 \mathrm{a}), 5.63$ (m, H-3), (6.29-6.32 (H-3'/H-3"'/H-5'/H-5"), 7.30-7.55 (5H, $m$, Ph) (Figs. S26-S27).

Preparation of (S)- and (R)-MTPA Esters of 5. 
$(R)-(-)$ and $(S)-(+)-M T P A-C l(23 \mu \mathrm{L})$ were separately added to two different aliquots of 5 (each $2 \mathrm{mg}$ ) in $200 \mu \mathrm{L}$ anhydrous pyridine. The resulting mixtures were allowed to stand at room temperature for 10 days and were monitored everyday by TLC. The products were separated by column chromatography to obtain $\mathbf{5} \boldsymbol{R}$ and $\mathbf{5 S}$. ${ }^{1} \mathrm{H}$ NMR of $\mathbf{5} \boldsymbol{R}$ and $\mathbf{5 S}\left(\mathrm{CDCl}_{3}, 400 \mathrm{MHz}\right)$ (Figs. S52-S54).

\subsubsection{Orsellinylmontagnetol A (1)}

White amorphous powder; ${ }^{[\alpha]_{D}^{25}}+168.0$ (c 0.2, methanol). UV (EtOH) $\lambda_{\max }(\log \varepsilon) 217(3.5)$, 266 (3.3), 302 (2.9) nm. FTIR (KBr) $v_{\max }$ 3441, 1636, 1451, 1389, $1049 \mathrm{~cm}^{-1}$. HR-ESI-MS $m / z$ $421.1128[\mathrm{M}-\mathrm{H}]^{-}$(calcd for $\mathrm{C}_{20} \mathrm{H}_{22} \mathrm{O}_{10}-\mathrm{H}, 421.1140$ ). ${ }^{1} \mathrm{H}$ and ${ }^{13} \mathrm{C}$ NMR (acetone- $d_{6}$ ) see Table 1. Standard t.1.c. $\mathrm{R}_{\mathrm{F}}$ values: $\mathrm{R}_{\mathrm{F}}(\mathrm{A}): 0.16 ; \mathrm{R}_{\mathrm{F}}(\mathrm{C}): 0.11 ; \mathrm{R}_{\mathrm{F}}(\mathrm{F}): 0.17 ; \mathrm{R}_{\mathrm{F}}(\mathrm{G}): 0.26 ; \mathrm{R}_{\mathrm{F}}(\mathrm{H}): 0.61$. Vanillin/ $\mathrm{H}_{2} \mathrm{SO}_{4}$ spray: red. HPLC $\mathrm{R}_{\mathrm{T}}$ value: $11.8 \mathrm{~min}$.

\subsubsection{Orsellinylmontagnetol B (2)}

White amorphous powder; $\left.{ }^{\alpha}\right]_{D}^{25}+580.0$ (c 0.1, methanol). UV (EtOH) $\lambda_{\max }(\log \varepsilon) 217$ (3.6), 266 (3.4), 302 (3.0) nm. FTIR (KBr) $v_{\max }$ 3449, 1636, 1458, 1389, $1049 \mathrm{~cm}^{-1}$. HR-ESI-MS m/z $445.1103[\mathrm{M}+\mathrm{Na}]^{+}$(calcd for $\mathrm{C}_{20} \mathrm{H}_{22} \mathrm{O}_{10} \mathrm{Na}, 445.1116$ ). ${ }^{1} \mathrm{H}$ and ${ }^{13} \mathrm{C}$ NMR (acetone- $d_{6}$ ) see Table 1. Standard t.1.c. $\mathrm{R}_{\mathrm{F}}$ values: $\mathrm{R}_{\mathrm{F}}(\mathrm{A}): 0.27 ; \mathrm{R}_{\mathrm{F}}(\mathrm{F}): 0.21 ; \mathrm{R}_{\mathrm{F}}(\mathrm{G}): 0.33 ; \mathrm{R}_{\mathrm{F}}(\mathrm{H}): 0.63$. Vanillin $/ \mathrm{H}_{2} \mathrm{SO}_{4}$ spray: red. HPLC $\mathrm{R}_{\mathrm{T}}$ value: $14.1 \mathrm{~min}$.

\subsubsection{Orsellinylmontagnetol C (3)}

White amorphous powder; $[\alpha]_{D}^{25} 0$ (c 0.1 , methanol). UV (EtOH) $\lambda_{\max }(\log \varepsilon) 217$ (3.5), 266 (3.2), 302 (2.9) nm. FTIR (KBr) $v_{\max }$ 3449, 1643, 1458, 1381, $1049 \mathrm{~cm}^{-1}$. HR-ESI-MS m/z 445.1127 [M+Na $]^{+}$(calcd for $\mathrm{C}_{20} \mathrm{H}_{22} \mathrm{O}_{10} \mathrm{Na}, 445.1116$ ). ${ }^{1} \mathrm{H}$ and ${ }^{13} \mathrm{C}$ NMR (acetone- $d_{6}$ ) see Table 1. Standard t.l.c. $\mathrm{R}_{\mathrm{F}}$ values: $\mathrm{R}_{\mathrm{F}}(\mathrm{A}): 0.28 ; \mathrm{R}_{\mathrm{F}}(\mathrm{G}): 0.46 ; \mathrm{R}_{\mathrm{F}}(\mathrm{H}): 0.70$. Vanillin $/ \mathrm{H}_{2} \mathrm{SO}_{4}$ spray: red. HPLC $\mathrm{R}_{\mathrm{T}}$ value: 12.7 min.

\subsubsection{Orsellinylmontagnetol D (4)}

White amorphous powder; $[\alpha]_{D}^{25}+2182$ (c 0.1, methanol). UV (EtOH) $\lambda_{\max }(\log \varepsilon) 216$ (3.9), 266 (3.8), 304 (3.4) nm. FTIR (KBr) $v_{\max }$ 3449, 1636, 1458, 1389, $1049 \mathrm{~cm}^{-1}$. HR-ESI-MS $m / z$ $571.1489[\mathrm{M}-\mathrm{H}]^{-}$(calcd for $\mathrm{C}_{28} \mathrm{H}_{28} \mathrm{O}_{13}-\mathrm{H}, 571.1458$ ). ${ }^{1} \mathrm{H}$ and ${ }^{13} \mathrm{C}$ NMR (acetone- $d_{6}$ ) see Table 1. Standard t.1.c. $\mathrm{R}_{\mathrm{F}}$ values: $\mathrm{R}_{\mathrm{F}}(\mathrm{A})$ : 0.27; $\mathrm{R}_{\mathrm{F}}(\mathrm{G}): 0.40 ; \mathrm{R}_{\mathrm{F}}(\mathrm{H}): 0.70$. Vanillin $/ \mathrm{H}_{2} \mathrm{SO}_{4}$ spray: red.

\subsubsection{Hydrofurylmontagnetol (5)}


White amorphous powder; ${ }^{[\alpha]_{D}^{25}}+227$ (c 0.1, methanol). UV (EtOH) $\lambda_{\max }(\log \varepsilon) 217$ (3.8), 267 (3.6), 304 (3.2) nm. FTIR (KBr) $v_{\max }$ 3456, 1643, 1458, 1389, $1049 \mathrm{~cm}^{-1}$. HR-ESI-MS m/z $277.0739[\mathrm{M}+\mathrm{Na}]^{+}$(calcd for $\left.\mathrm{C}_{12} \mathrm{H}_{14} \mathrm{O}_{6} \mathrm{Na}, 277.0692\right) .{ }^{1} \mathrm{H}$ NMR (Acetone- $\left.d_{6}, 500 \mathrm{MHz}\right): 2.50(s$, $\left.6^{\prime}-\mathrm{CH}_{3}\right), 3.70(d d, J=9.0,6.0 \mathrm{~Hz}, \mathrm{H}-4 \mathrm{~b}), 3.94(d d, J=10.0,4.0 \mathrm{~Hz}, \mathrm{H}-1 \mathrm{~b}), 4.00(d d, J=9.0,6.0$ $\mathrm{Hz}, \mathrm{H}-4 \mathrm{a}), 4.10$ (dd, $J=10.0,5.5 \mathrm{~Hz}, \mathrm{H}-1 \mathrm{a}), 4.59$ (ddd, $J=6.0,6.0,5.5 \mathrm{~Hz}, \mathrm{H}-3), 5.45$ (ddd, $J=$ 5.5, 5.5, 4.0 Hz, H-2), $6.23\left(d, J=2.0 \mathrm{~Hz}, \mathrm{H}-3{ }^{\prime}\right), 6.27$ (d, $\left.J=2.0 \mathrm{~Hz}, \mathrm{H}-5{ }^{\prime}\right) .{ }^{13} \mathrm{C}$ NMR (Acetone- $d_{6}$, $125 \mathrm{MHz}): 70.9$ (C-1), 75.4 (C-2), 71.0 (C-3), 72.7 (C-4), $105.6\left(\mathrm{C}-1^{\prime}\right), 165.6\left(\mathrm{C}-2^{\prime}\right), 101.6\left(\mathrm{C}-3^{\prime}\right)$, $163.0\left(\mathrm{C}^{-} 4^{\prime}\right), 112.3\left(\mathrm{C}-5^{\prime}\right), 144.7\left(\mathrm{C}-6^{\prime}\right), 171.3\left(\mathrm{C}-7^{\prime}\right), 24.2\left(6^{\prime}-\mathrm{CH}_{3}\right)$. Standard t.1.c. $\mathrm{R}_{\mathrm{F}}$ values: $\mathrm{R}_{\mathrm{F}}$ (A): $0.43 ; \mathrm{R}_{\mathrm{F}}(\mathrm{C}): 0.11 ; \mathrm{R}_{\mathrm{F}}(\mathrm{G}): 0.42 ; \mathrm{R}_{\mathrm{F}}(\mathrm{F}): 0.38 ; \mathrm{R}_{\mathrm{F}}(\mathrm{H}): 0.69$. Vanillin $/ \mathrm{H}_{2} \mathrm{SO}_{4}$ spray: red.

\subsection{Biological assays}

Cytotoxic activities of five isolated compounds against the HeLa (human epithelial cancer), HepG2 (liver hepatocellular carcinoma), MCF-7 (human breast cancer), NCI-H460 (human lung cancer) cell lines were performed at the concentration of $100 \mu \mathrm{g} / \mathrm{mL}$ using the Sulforhodamine B (SRB) assay with camptothecin as the positive control. Details were presented in Supporting information.

\section{Acknowledgements}

This research was supported by Vietnam's National Foundation for Science and Technology Development (NAFOSTED) grant \#104.01-2013.17. This work was also supported partly by University of Rennes 1 through a scholarship for Duong T.H. from January to April 2016. The authors would like to thank Dr. Wetchasart Polyiam, Lichen Research Unit, Department of Biology, Faculty of Science, Ramkhamhaeng University for the initial determination of the studied lichen. Aurélie Sauvager and Solenn Ferron are gratefully acknowledged for their valuable technical support.

\section{Conflict of Interest}

The authors have declared that there is no conflict of interest.

\section{References}

Aptroot, A., Schumm, F. 2011. Fruticose Roccellaceae, an anatomical-microscopical atlas and guide with a worldwide key and further notes on some crustose Roccellaceae or similar lichens. Norderstedt, pp. 1-380. 
Aberhart, D.J., Overton, K.H. 1969. Studies on lichen substances. Part LXII Aromatic constituents of the lichen Roccella fuciformis DC. A revised structure for lepraric acid. J. Chem. Soc. 704-707.

Basset, J.F., Leslie, C., Hamprecht, D., White, A.J.P., Barrett, A.G.M., 2010. Studies on the resorcylates: biomimetic total syntheses of $(+)$-montagnetol and $(+)$-erythrin. Tetrahedron Lett. $51,783-785$.

Brovetto, M., Seoane, G. 2008. Stereoselective synthesis of 3-oxygenated-cis-dialkyl-2,5-substituted tetrahydrofurans from cyclohexadienediols. J. Org. Chem. 73(15), 5776-5785.

Bohman-Lindgren, G., Ragnarsson, U., 1972. Chemical studies on lichens - XXXIV The synthesis of cyclo-( $R$ - $\beta$-phenyl- $\beta$-alanyl- $L$-prolyl-), a peptide isolated from Roccella canariensis. Tetrahedron 28, 4631-4634.

Boustie, J., Grube, M. 2005. Lichens-a promising source of bioactive secondary metabolites, Plant Genet. Resour. 3(2), 273-287.

Culberson, C.F. 1969. Chemical and botanical guide to lichen products. Univ. North Carolina Press, Chapel Hill.

Carbonero, E.R., Cordeiro, L.M.C., Mellinger, C.G., Sassaki, G.L., Stocker-Woergoetter, E., Gorin, P.A.J., Iacomini, M., 2005. Galactomannans with novel structures from the lichen Roccella decipiens Darb. Carbohydr. Res. 340(10), 1699-1705.

Duong, T.H., Chavasiri, W., Boustie, J., Nguyen, K.P.P. 2015. New meta-depsidones and diphenyl ethers from the lichen Parmotrema tsavoense (Krog \& Swinscow) Krog \& Swinscow, Parmeliaceae. Tetrahedron 71, 9684-9691.

Elix, J.A. Gaul, K.L. 1986. The interconversion of the lichen depsides para- and meta-scrobiculin, and the biosynthesis implications. Aust. J. Chem. 39, 613-624.

Elix, J.A. 2014. A catalogue of standardized chromatographic data and biosynthetic relationship for lichen substances. $3^{\text {rd }}$ Ed.; Published by the author. Canberra.

Feige, G.B., Viethen, B., Geyer, M.; Follmann, G. 1986. Phytochemistry of the lichen family Roccellaceae Chev. I. Secondary products and chemotypes of Roccella hypomecha (Ach.) Bory. J. Hattori Bot. Lab. 60, 143-148.

Feige, G.B., Kremer, B.P., 1980. Unusual carbohydrate pattern in Trentepohlia species. Phytochemistry 19(8), 1844-1845.

Grube M., Berg G., 2009 Microbial consortia of bacteria and fungi with focus on the lichen symbiosis. Fungal Biol. Rev., 23(3), 72-85.

Hawkes, G.E., Lewis, D., 1984. ${ }^{1} \mathrm{H}$ nuclear magnetic resonance spectra and conformations of alditols in deuterium oxide. J. Chem. Soc. Perkin Trans. II 2073-2078. 
Hesse, O. 1906. Contribution for the knowledge of the lichens and their characteristics components. J. fuer Praktische Chemie (Leipzig) 73(2), 113-176.

Hoye, T.R., Jeffrey, C.S., Shao, F., 2007. Mosher ester analysis for the determination of absolute configuration of stereogenic (chiral) carbinol carbons. Nat. Protocols 2(10), 2451-2458.

Huneck, S., Follmann, G. 1967. Lichen components. XLVIII. Components of Combea mollsca, Roccella vicentina, Roccella gayana and Roccella fucoides. Zeischrift fuer Naturforschung, Teil B: Anorganische Chemie, Organische Chemie, Biochemie, Biophysik, Biologie, 22(12), $1369-1370$.

Huneck, S., 1972. Lichen constituents. XC. 6-(Hydroxymethyl)leugenitin, a new chromone from Roccella fuciformis. Phytochemistry 11, 1489-1490.

Huneck, S., Jakupovic, J., Follmann, G., 1991. 3-O-Methylpannaric acid from the lichen Roccella capensis. Z. Naturforsch 46b, 969-970.

Huneck, S., Jakupovic, J., Follmann, G., 1992. The final structures of the lichen chromones galapagin, lobodirin, mollin, and roccellin. Z. Naturforsch 47b, 449-451.

Huneck, S., Elix, J.A., Naidu, R., Follmann, G., 1993. 3-O-Demethylschizopeltic acid, a new dibenzofuran from the lichen Roccella hypomecha, Aust. J. Chem. 46, 407-410.

Huneck, S., Yoshimura, I., 1996. Identification of lichen substances. Springer-Verlag, Berlin, pp. $229-235,328,347$.

Huneck, S. 2001. New Results on the Chemistry of Lichen Substances. Springer-Verlag Wien.

Ingavat, N., Dobereiner, J., Wiyakrutta, S., Mahidol, C., Ruchirawat, S., Kittakoop, P. 2009. Aspergillusol A, an $\alpha$-glucosidase inhibitor from the marine-derived fungus Aspergillus aculeatus, J. Nat. Prod. 72, 2049-2052.

Kubota, T., Tsuda, M., Kobayashi, J. 2002. Absolute stereochemistry of amphidinolide E. J. Org. Chem. 67, 1651-1656.

Le Pogam, P., Legouin, B., Le Lamer, A.C., Boustie, J., Rondeau, D., 2015. Analysis of the cyanolichen Lichina pygmaea using in situ DART-MS: from detection to thermochemistry of mycosporine serinol. J. Mass Spectrom. 50(3), 454-462

Le Pogam, P., Le Lamer, A.C., Legouin B., Boustie, J., Rondeau, D., 2016. In situ DART-MS as a versatile and rapid dereplication tool in lichenology: chemical fingerprinting of Ophioparma ventosa, Phytochemical Analysis, DOI 10.1002/pca.2635.

Lopes, T.I.B., Coelho, R.G., Yoshida, N.C., Honda, N.K., 2008. Radical-scavenging activity of orsellinates. Chem. Pharm. Bull. 56(11), 1551-1554.

Mihelich, E.D., Hite, G.A., 1992. Stereochemical course of direct ring closures of complex homoallylic alcohols to substituted tetrahydrofurans. J. Am. Chem. Soc. 114, 7318-7319. 
Muller, C.E., Zell D., Schreiner, P.R. 2009. One-pot desymmetrization of meso-1,2-hydrocarbon diols through acylation and oxidation. Chem. Eur. J. 15, $9647-9650$.

Murty, T.K., Subramanian S.S. 1958, Carotene content of Roccella montagnei. J. Sci. Ind. Res. 17C, $105-106$.

Murty, T.K., Subramanian S.S. 1959, Isolation of ergosterol from Roccella montagnei. J. Sci. Ind. Res. 18B, 91-92.

Nash III, T. H. 2008. Lichen Biology, $2^{\text {nd }}$ Ed., Cambridge Univ. Press., Cambridge, New York.

Parrot, D., Peresse, T., Hitti, E., Carrie, D., Grube, M., Tomasi, S. 2015. Qualitative and spatial metabolite profiling of lichens by a LC-MS approach combined with optimised extraction. Phytochem. Anal. 26, 23-33.

Pavlik, C., Onorato, A., Castro, S., Morton M., Peczuh M., Smith, M.B. 2009 An unexpectedly facile cyclization of polyhydric alcohols. Org. Lett. 11(16), 3722-3725.

Ramakrishnan, S., Subramanian, S.S. 1964. Amino acids of Roccella montagnei and Parmelia tinctorum. Indian J. Chem. 2(11), 467.

Richardson, D.H.S., Hill, D.J., Smith, D.C. 1968. Lichen physiology-XL The role of the alga in determining the pattern of carbohydrate movement between lichen symbionts. New Phytol. 67, 469-486.

Skehan, P., Storeng, R., Scudiero, D., Monks, A., McMahon, J., Vistica, D., Warren, J.T., Bokesch, H., Kenney, S., Boyd, M.R., 1990. New colorimetric cytotoxicity assay for anticancer-drug screening. J. Natl. Cancer Inst. 82, 1107-1112.

Spribille, T., Tuovinen, V., Resl, P., Vanderpool, D., Wolinski, H., Aime, M.C., Schneider, K., Stabentheiner, E., Toome-Helle, M., Thor, G., Mayrhofer, H., Johannesson, H., McCutcheon, J.P., 2016. Basidiomycete yeasts in the cortex of ascomycete macrolichens. Science 353, 488492.

Stocker-Wörgötter, E. 2008. Metabolic diversity of lichen-forming ascomycetous fungi: culturing, polyketide and shikimate metabolite production, and PKS genes. Nat. Pro. Rep. 25, 188-200.

Tehler, A., Irestedt, M., Wedin, M., Ertz, D. 2010. The old world Roccella species outside Europe and Macaronesia: taxonomy, evolution and phylogeny. Syst. Biodivers. 8(2), 223-246.

Thadhani, V. M., Choudhary, M. I., Andersen, R. J., Karunaratne, V. 2010. Novel entry into 5decarboxydibenzofurans via Smiles rearrangement of the lichen para-depside, erythrin. J. Chem. Res. 34, 154-157.

Tsuda, M., Toriyabe, Y., Endo, T., Kobayashi, J., 2003. Application of modified Mosher's method for primary alcohols with a methyl group at C2 position. Chem. Pharm. Bull. 51(4), 448-451. 
Tsuda, M., Sasaki, M., Mugishima, T., Komatsu, K., Sone, T., Tanaka, M., Mikami, Y., Kobayashi, J. 2005. Scalusamides A-C, new pyrrolidine alkaloids from the marine-derived fungus Penicillium citrinum. J. Nat. Prod. 68, 273-276.

Wang, H., Ning, R., Shen, Y., Chen, Z., Li, J., Zhang, R., Leng ,Y., Zhao ,W. 2014. Lithocarpic acids A-N, 3,4-seco-cycloartane derivatives from the cupules of Lithocarpus polystachyus. J. Nat. Prod. 77, 1910-1920.

Williams, D.R, Harigaya, Y., Moore, J.L., D’sa, A.. 1984. Stereocontrolled transformations of orthoester intermediates into substituted tetrahydrofurans. J. Am. Chem. Soc. 106, 2641-2644.

Yoshimatsu, M., Naito, M., Shimizu, H., Muraoka, O., Tanabe, G., Kataoka, T. 1996. Stereospecific syntheses of 5-alkyl-3-ethoxy-2-((phenylchalcogeno)methylene)tetrahydrofurans. J. Org. Chem. 61(23), 8200-8206.

Yasuhara, F., Yamaguchi, S., Kasai, R., Tanaka, O. 1986. Assignment of absolute configuration of 2substituted-1-propanols by ${ }^{1}$ H-NMR spectroscopy. Tetrahedron Lett. 27(34), 4033-4034.<smiles>[R]OC[C@@H](O[R2])[C@@H](O[R2])[C@H](C)OC(=O)c1c(C)cc(O)cc1O</smiles>

$1 \quad \mathrm{R}^{1}=\mathrm{H}$

$1 S \quad \mathrm{R}^{1}=(S)$-МTPA

$\mathrm{R}^{2}=\mathrm{H}$

$\mathrm{R}^{2}=\mathrm{H}$

$\mathrm{R}^{3}=\mathrm{X}$

$1 \boldsymbol{R} \quad \mathrm{R}^{1}=(R)$-MTPA

$2 \mathrm{R}^{1}=\mathrm{H}$

$\mathrm{R}^{2}=\mathrm{H}$

$=X$

$$
2 S
$$

$$
2
$$

$\mathrm{R}^{3}=\mathrm{X}$

$\mathrm{R}^{3}=\mathrm{H}$

$\mathrm{R}^{3}=\mathrm{H}$

$\mathrm{R}^{3}=\mathrm{H}$

\section{?}

$$
3
$$

$4 \quad \mathrm{R}^{1}=\mathrm{X}$

$6 \quad \mathrm{R}^{1}=\mathrm{H}$<smiles>[X]C(=O)c1c(C)cc(O)cc1O</smiles>

$\mathrm{R}^{3}=\mathrm{H}$

$\mathrm{R}^{3}=\mathrm{X}$

$\mathrm{R}^{3}=\mathrm{H}$<smiles>Cc1cc(O)cc(O)c1C(=O)OC1COCC1O</smiles>

5<smiles>CC(=O)OC[C@@H](O)[C@H](O)CO</smiles>

7<smiles>[R]c1c(C)cc(OC(=O)c2c(C)cc(O)cc2O)cc1O</smiles><smiles>O=C(C=[W])OC[C@@H](O)[C@@H](O)CO</smiles>

$9 \mathrm{R}=\mathrm{COOH}$

$10 \mathrm{R}=\mathrm{H}$<smiles>[R]c1c(C)cc(O)cc1O</smiles>

$11 \mathrm{R}=\mathrm{COOH}$

$12 \mathrm{R}=\mathrm{COOCH}_{3}$

Fig. 1. Chemical structures of 1-12 


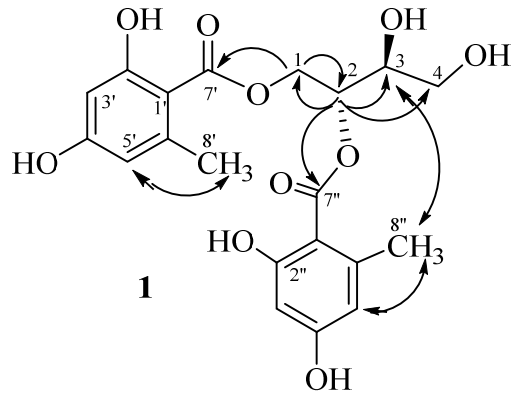

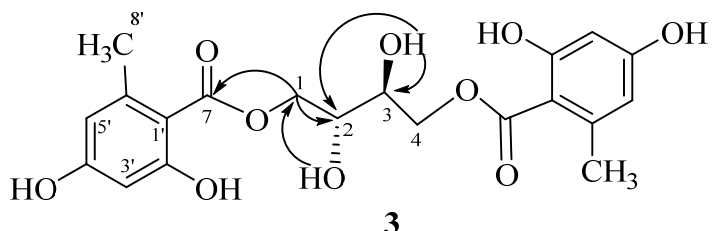

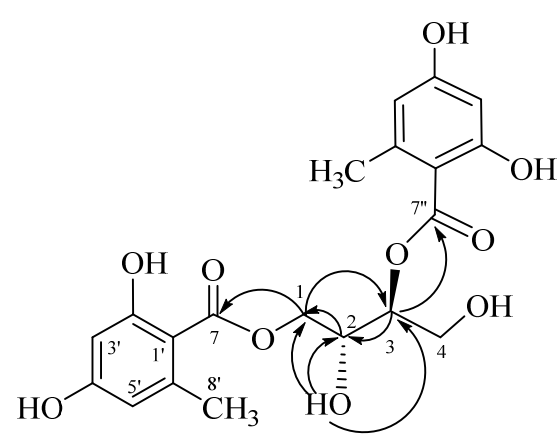

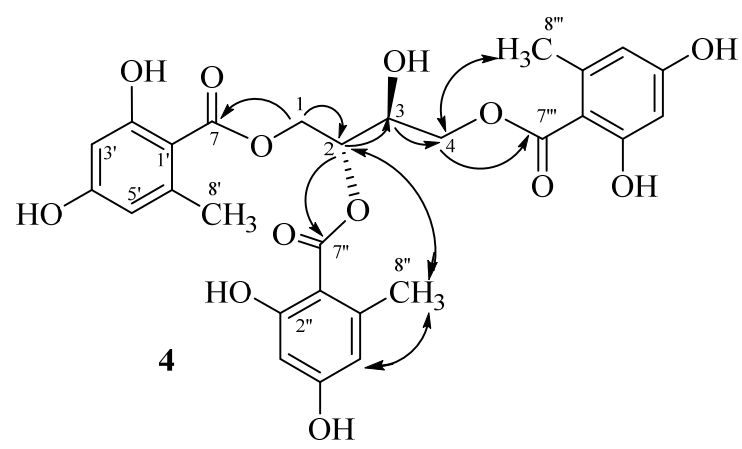

Fig. 2. Key HMBC and NOESY correlations of compounds 1-4

$15 \Delta \delta_{4 \mathrm{a}, 4 \mathrm{~b}}=0.200 \mathrm{ppm}$

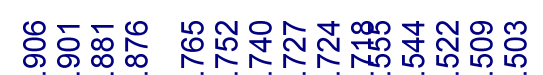

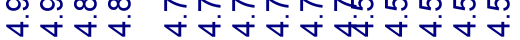

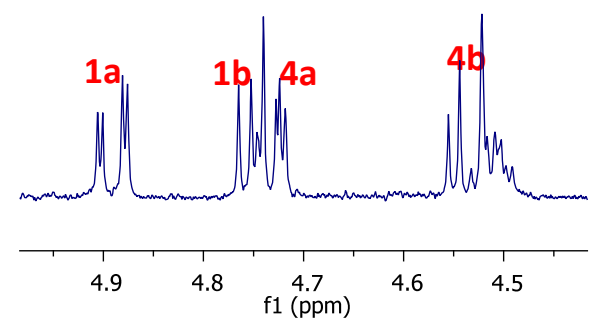

$1 R \quad \Delta \delta_{4 \mathrm{a}, 4 \mathrm{~b}}=\mathbf{0 . 0 7 0 \mathrm { ppm }}$

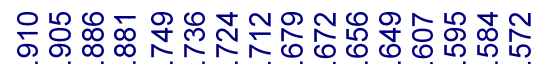

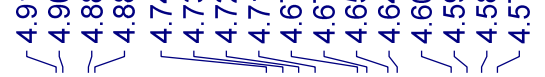

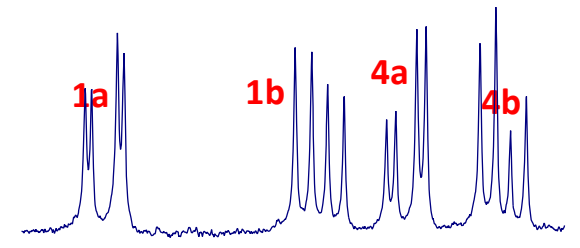

$\begin{array}{lllllllll}4.95 & 4.90 & 4.85 & 4.80 & 4.75 & 4.70 & 4.65 & 4.60 & 4.55\end{array}$
$2 S \quad \Delta \delta_{4 \mathrm{a}, 4 \mathrm{~b}}=\mathbf{0 . 0 6 0} \mathrm{ppm}$

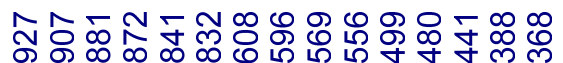

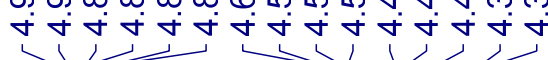

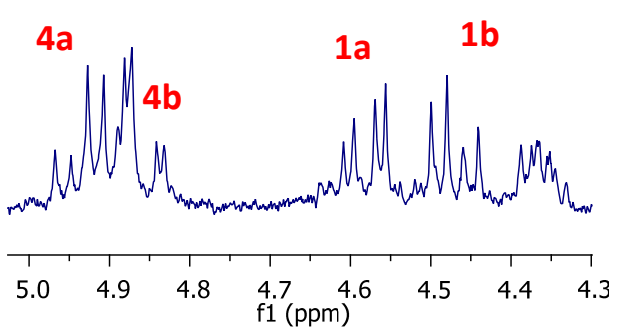

$2 R \quad \Delta \delta_{4 \mathrm{a}, 4 \mathrm{~b}}=\mathbf{0 . 0 2 0} \mathrm{ppm}$
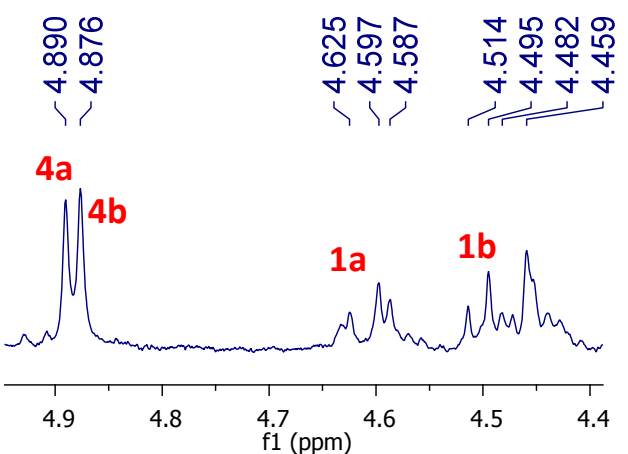

Fig. 3. Proton signal patterns of $\mathrm{H}_{2}-4$ of $(S)$ - and $(R)$-MTPA esters ( $\mathbf{1} S$ and $\mathbf{1} \boldsymbol{R}$, respectively) (left) and ( $2 S$ and $2 R$, respectively) (right) 


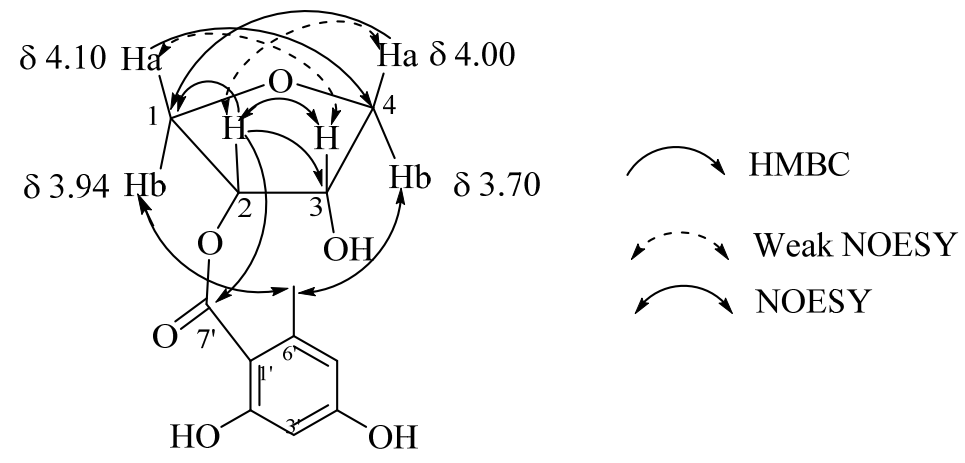

Fig. 4. Key HMBC and NOESY correlations of compound 5.

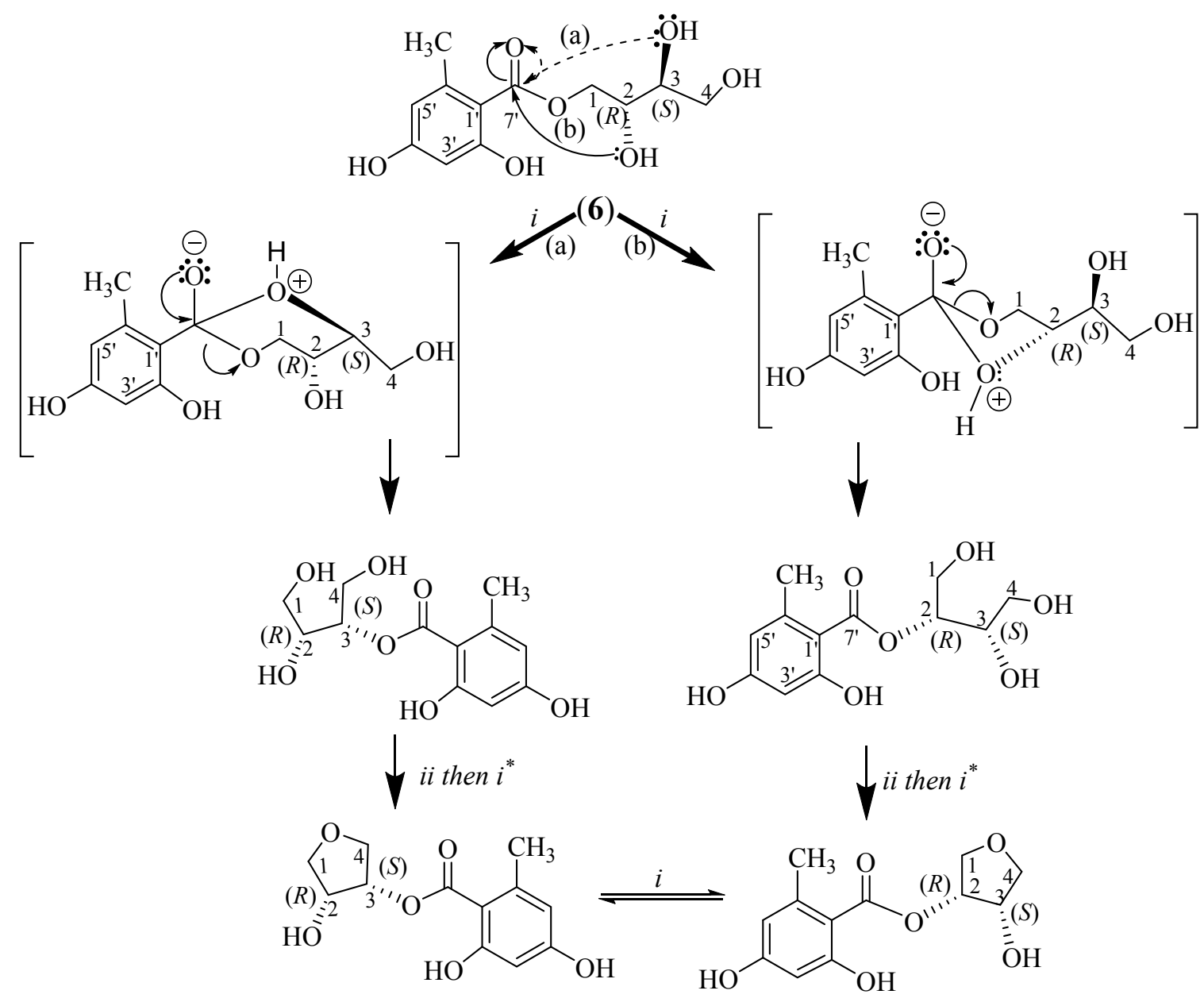

(5)

(5)

Scheme 1: The proposed biosynthetic pathway for the formation of compound $\mathbf{5}$ from D-montagnetol (6). [(i): transesterification; (ii): cyclodehydration]. *or vice versa 
Table 1 NMR spectroscopic data of compounds 1-4

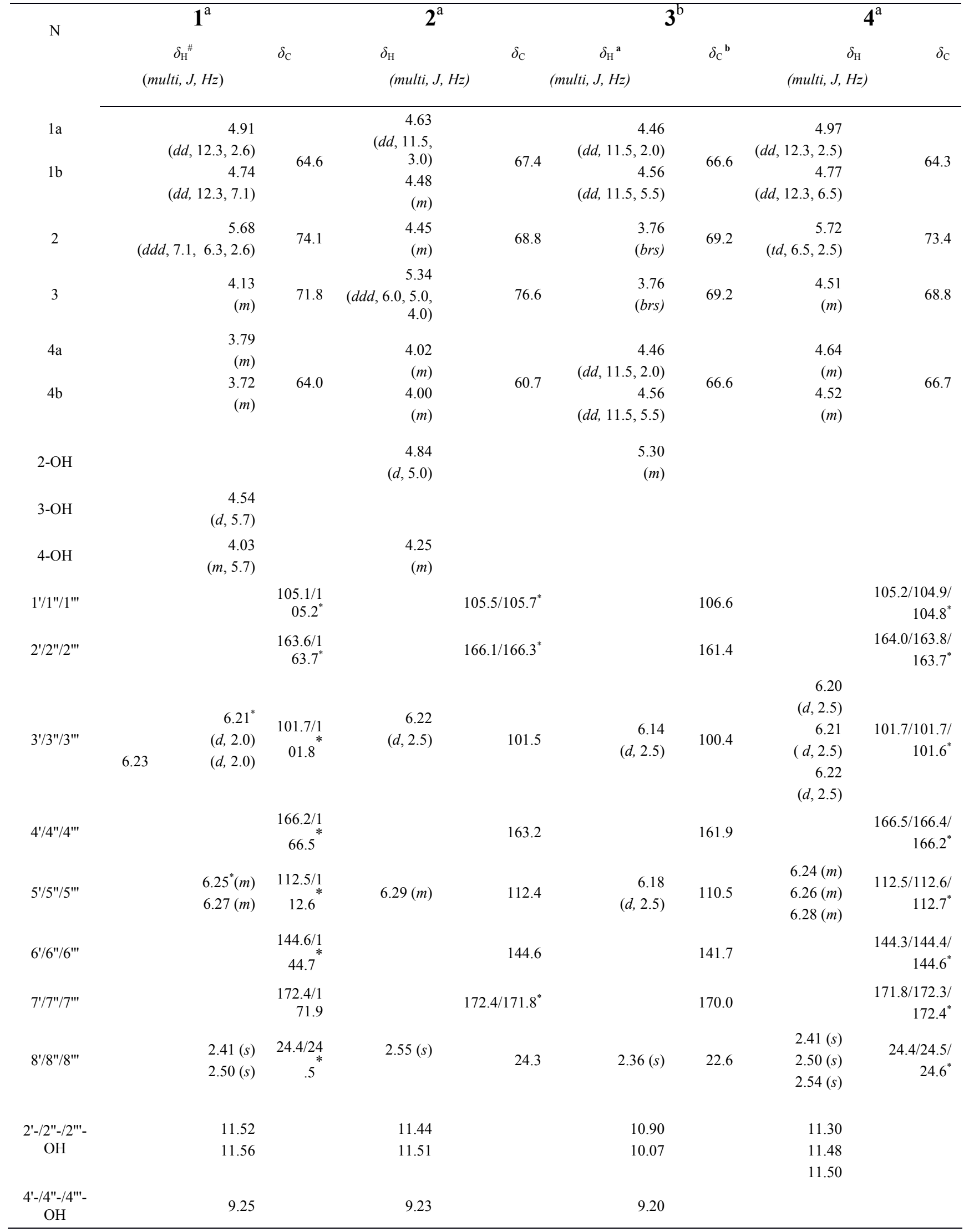

All spectra were recorded ${ }^{\mathrm{a}}$ in acetone- $d_{6} ;{ }^{\mathrm{b}}$ in DMSO- $d_{6}$; ${ }^{\#}$ : recorded at $300 \mathrm{MHz} ;{ }^{*}$ Values in each line or column (of each compound) could be interchanged 